Prepared in cooperation with the

Pennsylvania Department of Conservation and Natural Resources,

Bureau of Topographic and Geologic Survey

\title{
Baseline Groundwater Quality from 34 Wells in Wayne County, Pennsylvania, 2011 and 2013
}

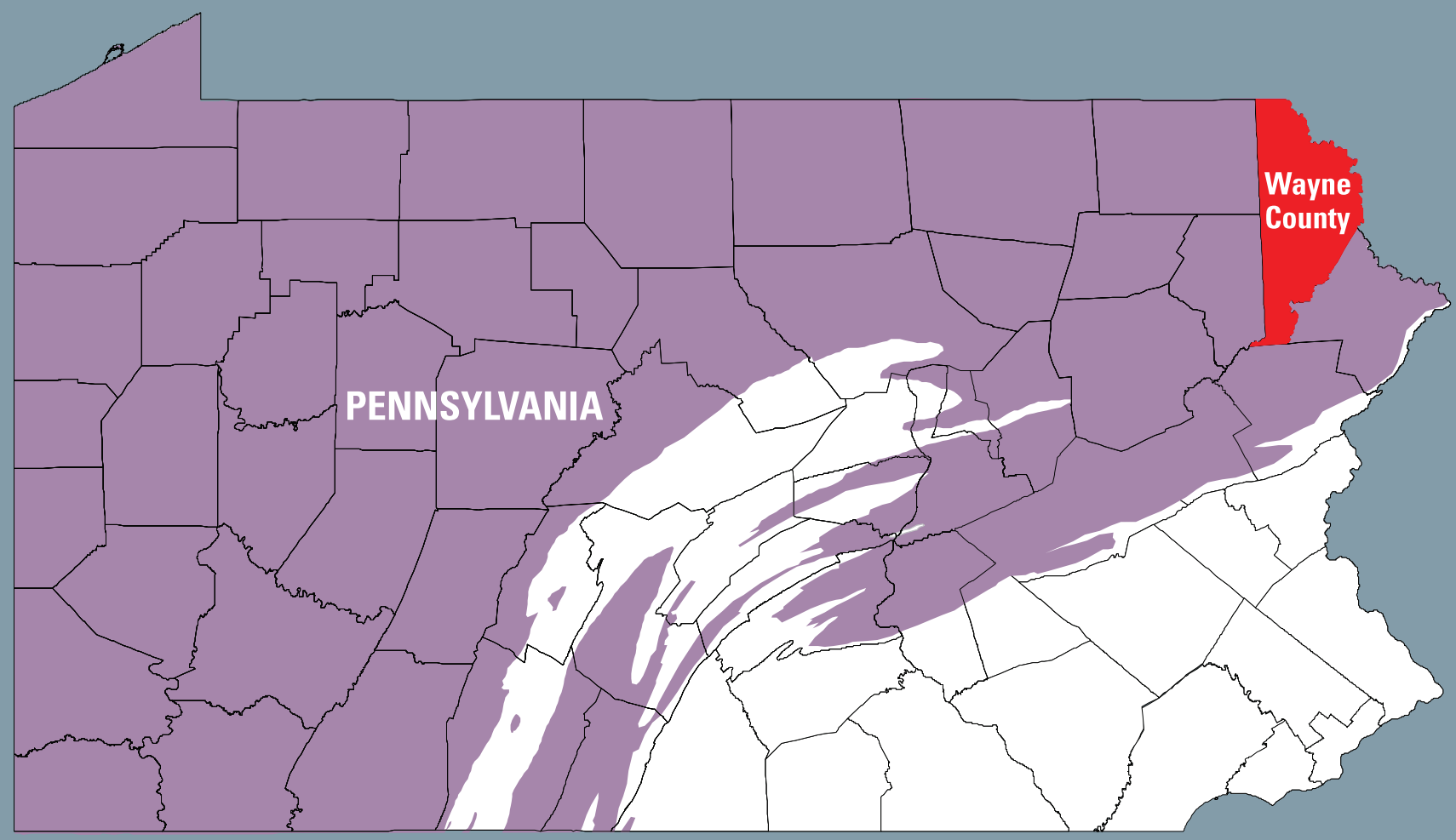

Open-File Report 2014-1116

U.S. Department of the Interior U.S. Geological Survey 
Cover. Location of Wayne County, Pennsylvania, and the shaded extent of the underlying Marcellus Shale. Refer to figure 1. 


\section{Baseline Groundwater Quality from 34 Wells in Wayne County, Pennsylvania, 2011 and 2013}

By Ronald A. Sloto

Prepared in cooperation with the

Pennsylvania Department of Conservation and Natural Resources,

Bureau of Topographic and Geologic Survey

Open-File Report 2014-1116 


\title{
U.S. Department of the Interior SALLY JEWELL, Secretary
}

\section{U.S. Geological Survey Suzette M. Kimball, Acting Director}

\author{
U.S. Geological Survey, Reston, Virginia: 2014
}

\begin{abstract}
For more information on the USGS - the Federal source for science about the Earth, its natural and living resources, natural hazards, and the environment, visit http://www.usgs.gov or call 1-888-ASK-USGS

For an overview of USGS information products, including maps, imagery, and publications, visit http://www.usgs.gov/pubprod

To order this and other USGS information products, visit http://store.usgs.gov
\end{abstract}

Any use of trade, product, or firm names is for descriptive purposes only and does not imply endorsement by the U.S. Government.

Although this report is in the public domain, permission must be secured from the individual copyright owners to reproduce any copyrighted materials contained within this report.

Suggested citation:

Sloto, R.A., 2014, Baseline groundwater quality from 34 wells in Wayne County, Pennsylvania, 2011 and 2013:

U.S. Geological Survey Open-File Report 2014-1116, 24 p., http://dx.doi.org/10.3133/ofr20141116.

ISSN 2331-1258 (online) 


\section{Acknowledgments}

The cooperation of the residents of Wayne County who made their wells accessible for sampling is greatly appreciated. The author thanks Dana Heston of the Pennsylvania Geological Survey for her assistance with well location and sampling. Water samples were collected by Tia-Marie Scott, Paul Heisig, and Richard Reynolds of the U.S. Geological Survey. 


\section{Contents}

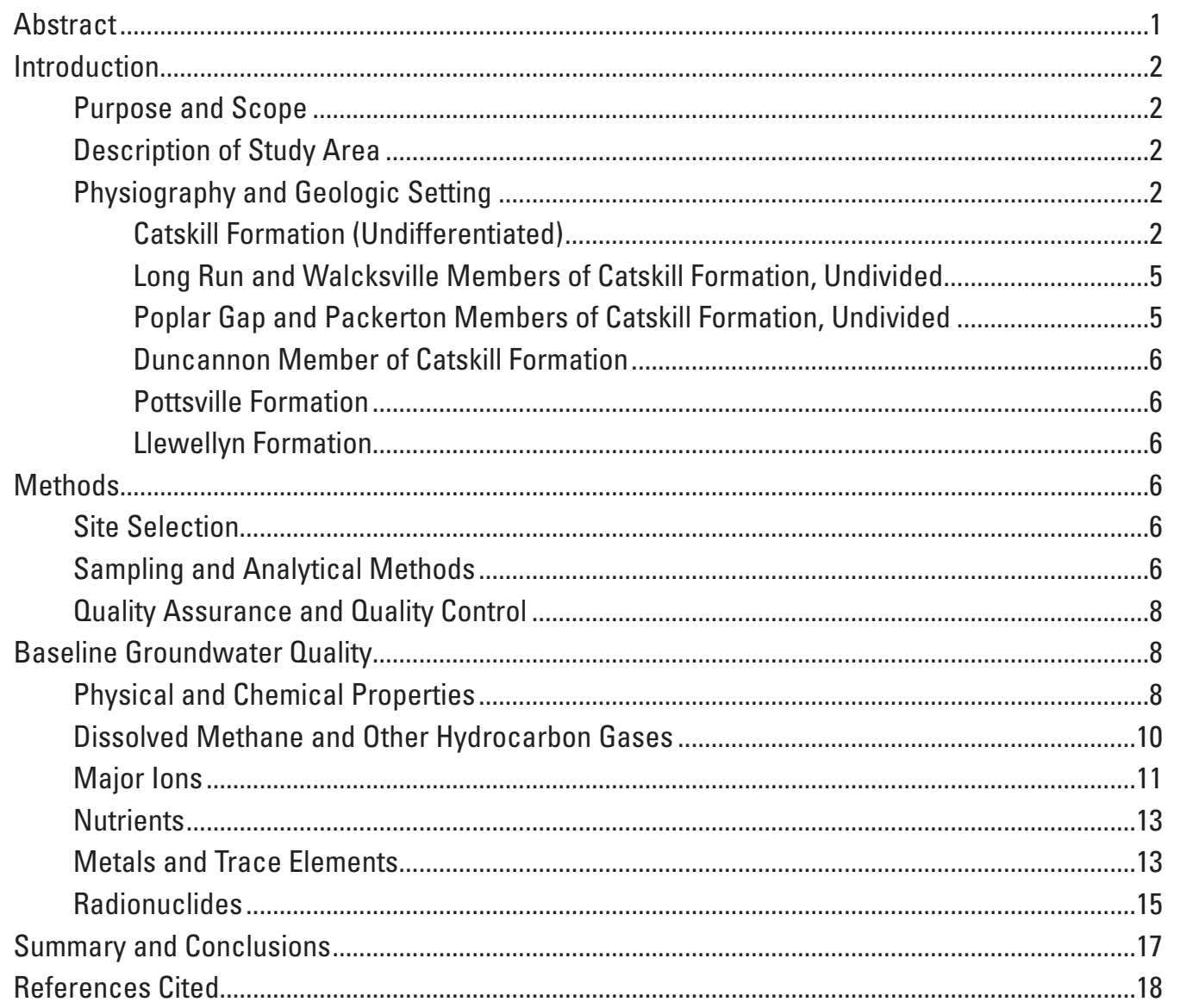




\section{Figures}

1. Map showing location of Wayne County, Pennsylvania

2. Map showing geology and location of sampled wells, Wayne County, Pennsylvania

3. Stratigraphic correlation chart for Wayne County, Pennsylvania

4. Graph showing relation between $\mathrm{pH}$ and dissolved oxygen concentration in groundwater samples collected from 34 wells in Wayne County, Pennsylvania

5. Graph showing relation between $\mathrm{pH}$ and dissolved methane concentration in groundwater samples collected from 34 wells in Wayne County, Pennsylvania

6. Graph showing stable isotopic composition of carbon and hydrogen in dissolved methane in three groundwater samples from Wayne County, Pennsylvania.

7. Graph showing relation between $\mathrm{pH}$ and arsenic concentration in groundwater samples collected from 34 wells in Wayne County, Pennsylvania

8. Graph showing relation between $\mathrm{pH}$ and boron, bromide, and lithium concentrations in groundwater samples collected from 34 wells in Wayne County, Pennsylvania.

9. Graph showing relation between $\mathrm{pH}$ and fluoride and sodium concentrations in groundwater samples collected from 34 wells in Wayne County, Pennsylvania

\section{Tables}

1. Characteristics of 34 wells sampled in Wayne County, Pennsylvania, 2011 and 2013

2. U.S. Environmental Protection Agency maximum contaminant, secondary contaminant, and action levels for constituents in drinking water

3. Summary statistics for physical properties and dissoved oxgen and methane concentrations in groundwater samples collected from 34 wells in Wayne County, Pennsylvania, 2011 and 2013

4. Summary statistics for concentrations of major ions in groundwater samples collected from 34 wells in Wayne County, Pennsylvania, 2011 and 2013

5. Summary statistics for concentrations of nutrients in groundwater samples collected from 34 wells in Wayne County, Pennsylvania, 2011 and 2013

6. Summary statistics for concentrations of metals and trace elements in groundwater samples collected from 34 wells in Wayne County, Pennsylvania, 2011 and 2013

7. Summary statistics for concentrations and activities of radioactive constituents in groundwater samples collected from 34 wells in Wayne County, Pennsylvania, 2011 and 2013

8. Physical properties and dissolved oxygen and methane concentrations for groundwater samples collected from 34 wells in Wayne County, Pennsylvania, 2011 and 2013

9. Concentrations of major ions in groundwater samples collected from 34 wells in Wayne County, Pennsylvania, 2011 and 2013.

10. Concentrations of nutrients in groundwater samples collected from 34 wells in Wayne County, Pennsylvania, 2011 and 2013

11. Concentrations of metals and trace elements in groundwater samples collected from 34 wells in Wayne County, Pennsylvania, 2011 and 2013.

12. Concentrations and activities of radioactive constituents in groundwater samples collected from 34 wells in Wayne County, Pennsylvania, 2011 and 2013 


\section{Conversion Factors and Datums}

\begin{tabular}{|c|c|c|}
\hline Multiply & By & To obtain \\
\hline \multicolumn{3}{|c|}{ Length } \\
\hline foot $(\mathrm{ft})$ & 0.3048 & meter $(\mathrm{m})$ \\
\hline mile (mi) & 1.609 & kilometer (km) \\
\hline \multicolumn{3}{|c|}{ Area } \\
\hline square mile $\left(\mathrm{mi}^{2}\right)$ & 2.590 & square kilometer $\left(\mathrm{km}^{2}\right)$ \\
\hline \multicolumn{3}{|c|}{ Volume } \\
\hline gallon (gal) & 3.785 & liter (L) \\
\hline \multicolumn{3}{|c|}{ Flow rate } \\
\hline gallon per minute (gal/min) & 0.06309 & liter per second $(\mathrm{L} / \mathrm{s})$ \\
\hline \multicolumn{3}{|c|}{ Radioactivity } \\
\hline picocurie per liter $(\mathrm{pCi} / \mathrm{L})$ & 0.037 & becquerel per liter $(\mathrm{Bq} / \mathrm{L})$ \\
\hline
\end{tabular}

Temperature in degrees Celsius $\left({ }^{\circ} \mathrm{C}\right)$ may be converted to degrees Fahrenheit $\left({ }^{\circ} \mathrm{F}\right)$ as follows:

$$
{ }^{\circ} \mathrm{F}=\left(1.8 \times{ }^{\circ} \mathrm{C}\right)+32
$$

Temperature in degrees Fahrenheit $\left({ }^{\circ} \mathrm{F}\right)$ may be converted to degrees Celsius $\left({ }^{\circ} \mathrm{C}\right)$ as follows:

$$
{ }^{\circ} \mathrm{C}=\left({ }^{\circ} \mathrm{F}-32\right) / 1.8
$$

Vertical coordinate information is referenced to North American Vertical Datum of 1988 (NGVD 88).

Horizontal coordinate information is referenced to North American Datum of 1983 (NAD 83).

Elevation, as used in this report, refers to distance above the vertical datum.

\section{Abbreviations}

$\begin{array}{ll}\text { AMCL } & \text { proposed alternate maximum contaminant levels } \\ \text { MCL } & \text { maximum contaminant level } \\ \text { PaGS } & \text { Pennsylvania Geological Survey } \\ \text { SMCL } & \text { secondary maximum contaminant level } \\ \text { USEPA } & \text { U.S. Environmental Protection Agency } \\ \text { USGS } & \text { U.S. Geological Survey } \\ \mathbf{\mu g} / \mathbf{L} & \text { micrograms per liter } \\ \mathbf{m g} / \mathbf{L} & \text { milligrams per liter } \\ \mathbf{\mu S / c m} & \text { microsiemens per centimeter at } 25 \text { degrees Celsius } \\ \mathbf{p C i / L} & \text { picocuries per liter }\end{array}$





\title{
Baseline Groundwater Quality from 34 Wells in Wayne County, Pennsylvania, 2011 and 2013
}

\author{
By Ronald A. Sloto
}

\section{Abstract}

Wayne County, Pennsylvania, is underlain by the Marcellus Shale, which currently (2014) is being developed elsewhere in Pennsylvania for natural gas. All residents of largely rural Wayne County rely on groundwater for water supply, primarily from bedrock aquifers (shales and sandstones). This study, conducted by the U.S. Geological Survey in cooperation with the Pennsylvania Department of Conservation and Natural Resources, Bureau of Topographic and Geologic Survey (Pennsylvania Geological Survey), provides a groundwater-quality baseline for Wayne County prior to development of the natural gas resource in the Marcellus Shale. Selected wells completed in the Devonian-age Catskill Formation, undifferentiated; the Poplar Gap and Packerton Members of the Catskill Formation, undivided; and the Long Run and Walcksville Members of the Catskill Formation, undivided, were sampled.

Water samples were collected once from 34 domestic wells during August 2011 and August and September 2013 and analyzed to characterize their physical and chemical quality. Samples were analyzed for 45 constituents and properties, including nutrients, major ions, metals and trace elements, radioactivity, and dissolved gases, including methane and radon-222. The quality of the sampled groundwater was generally within U.S. Environmental Protection Agency (USEPA) drinking-water standards, although in some samples, the concentrations of a few constituents exceeded USEPA drinkingwater standards and health advisories.

The $\mathrm{pH}$ of water samples ranged from 5.5 to 9.3 with a median of 7.0. The $\mathrm{pH}$ was outside the USEPA secondary maximum contaminant level (SMCL) range of 6.5 to 8.5 in water samples from 14 of the 34 wells (41 percent). Eleven samples had a pH less than 6.5, and three samples had a pH greater than 8.5. Dissolved oxygen concentrations ranged from 0.2 to 11.5 milligrams per liter $(\mathrm{mg} / \mathrm{L})$ with a median of $4.7 \mathrm{mg} / \mathrm{L}$. The dissolved oxygen concentration was less than $1 \mathrm{mg} / \mathrm{L}$ in water samples from 6 wells; 5 of these 6 water samples had a $\mathrm{pH}$ greater than 7.7.

Concentrations of dissolved methane ranged from less than 0.00006 to $3.3 \mathrm{mg} / \mathrm{L}$. Methane was detectable in 22 of the 34 wells sampled ( 65 percent). Methane concentrations were greatest in the 5 samples with $\mathrm{pH}$ of 7.8 or higher, ranging from 0.040 to $3.3 \mathrm{mg} / \mathrm{L}$. These samples also had among the lowest concentrations of dissolved oxygen. Three water samples, which had sufficient dissolved methane concentrations (greater than $0.9 \mathrm{mg} / \mathrm{L}$ ), were analyzed for isotopes of carbon and hydrogen in the methane. The isotopic ratio values fell within (two samples) or close to (one sample) the range for a thermogenic natural gas source.

The total dissolved solids concentration ranged from 33 to $346 \mathrm{mg} / \mathrm{L}$; the median concentration was $126 \mathrm{mg} / \mathrm{L}$. Sodium concentrations ranged from 1.07 to $116 \mathrm{mg} / \mathrm{L}$; the median concentration was $9.42 \mathrm{mg} / \mathrm{L}$. The sodium concentration exceeded the USEPA health advisory for sodium of $20 \mathrm{mg} / \mathrm{L}$ in water samples from 7 of the 34 wells ( 21 percent).

Concentrations of dissolved arsenic ranged from less than 0.06 to 21.8 micrograms per liter $(\mu \mathrm{g} / \mathrm{L})$; the median concentration was $0.59 \mu \mathrm{g} / \mathrm{L}$. Water samples from 2 of the 34 wells (6 percent) exceeded the USEPA maximum contaminant level (MCL) of $10 \mu \mathrm{g} / \mathrm{L}$ for arsenic. Concentrations of dissolved manganese ranged from less than 0.15 to $61.5 \mu \mathrm{g} / \mathrm{L}$; the median concentration was $0.42 \mu \mathrm{g} / \mathrm{L}$. A water sample from 1 of the 34 wells ( 3 percent) exceeded the USEPA SMCL of $50 \mu \mathrm{g} / \mathrm{L}$ for manganese; the concentration was less than the USEPA lifetime health advisory of $300 \mu \mathrm{g} / \mathrm{L}$ for manganese.

Activities of radon-222 in water from the 34 sampled wells ranged from 110 to 7,180 picocuries per liter (pCi/L); the median activity was $2,105 \mathrm{pCi} / \mathrm{L}$. Water samples from 33 of the 34 wells (97 percent) exceeded the proposed USEPA MCL of $300 \mathrm{pCi} / \mathrm{L}$, and 4 water samples (12 percent) exceeded the USEPA proposed alternative MCL of 4,000 $\mathrm{pCi} / \mathrm{L}$ for radon-222.

Differences in groundwater chemistry were related to $\mathrm{pH}$. Water with a $\mathrm{pH}$ greater than 7.6 generally had low dissolved oxygen concentrations, indicating reducing conditions in the aquifer. These high $\mathrm{pH}$ waters also had relatively elevated concentrations of methane, arsenic, boron, bromide, fluoride, lithium, and sodium but low concentrations of copper, nickel, and zinc. Water samples with a $\mathrm{pH}$ greater than 7.8 had methane concentrations equal to or greater than $0.04 \mathrm{mg} / \mathrm{L}$. 


\section{Introduction}

Wayne County, which is located in northeastern Pennsylvania (fig. 1), is underlain by the Marcellus Shale. The Marcellus Shale, which is being developed elsewhere in Pennsylvania for natural gas, lies approximately from less than 2,000 feet (ft) below land surface in southern Wayne County to more than 7,000 ft below land surface in western Wayne County. All residents of largely rural Wayne County rely on groundwater as a source of water supply. Drilling and hydraulic fracturing of horizontal natural gas wells have the potential to contaminate freshwater aquifers that provide drinking water and the base flow of streams (Kargbo and others, 2010; Kerr, 2010; U.S. Environmental Protection Agency, 2014). Because of a drilling moratorium imposed by the Delaware River Basin Commission in 2010 (Delaware River Basin Commission, 2014), only nine vertical exploratory gas wells have been drilled in Wayne County as of January 2014 (Pennsylvania Department of Environmental Protection, 2014a). No horizontal drilling has occurred, and no well has been hydraulically fractured. Since 2006, permits have been issued for 33 Marcellus Shale gas wells in Wayne County (Pennsylvania Department of Environmental Protection, 2014b).

Without baseline data for water-quality constituents, it is not possible to establish a connection between natural-gas production activities and the groundwater chemistry that might be affected. This study, conducted by the U.S. Geological Survey (USGS) in cooperation with the Pennsylvania Department of Conservation and Natural Resources, Bureau of Topographic and Geologic Survey [Pennsylvania Geological Survey $(\mathrm{PaGS})]$, provides a groundwater-quality baseline for Wayne County prior to production of natural gas from the Marcellus Shale.

This groundwater-quality assessment is intended to provide current data on the occurrence of methane and inorganic constituents in shallow groundwater (less than about 1,000 feet deep) in bedrock aquifers prior to shale-gas production in Wayne County. The assessment also may be used to help evaluate overall general groundwater quality in the county, identify constituents in groundwater that may pose a health risk, and serve as a baseline for future evaluations to determine the effect of shale-gas development on groundwater quality.

\section{Purpose and Scope}

This report presents analytical data for water samples collected from 34 selected wells in Wayne County in 2011 and 2013. The water samples were analyzed for 45 constituents and physical properties, including nutrients, major ions, metals, trace elements, radioactivity, and dissolved gases, including methane and radon-222. The groundwater-quality data and summary statistics are presented for selected constituents to provide a pre-gas-well drilling baseline. Only limited data interpretation is presented.

\section{Description of Study Area}

Wayne County, which occupies 750.5 square miles in northeastern Pennsylvania (fig. 1), is rural with a 2013 estimated population of 51,548 (U.S. Census Bureau, 2014). Seasonal dwellings (summer or vacation homes) made up 35.5 percent of housing units in the county in 2010 (Wayne County Planning Commission, 2010). In 2008, 65 percent of Wayne County was forested (Wayne County Planning Commission, 2010). Approximately 22 percent of the county was devoted to agriculture with about 11 percent of the land in pasture or brushland and 12.4 percent in cropland. About 8 percent of the county is developed with 6.2 percent of the land classified as residential and 0.9 percent classified as commercial.

\section{Physiography and Geologic Setting}

Most of Wayne County is located in the Glaciated Low Plateau Section of the Appalachian Plateaus Physiographic Province (fig. 1). A small part of western Wayne County is in the Anthracite Valley Section of the Ridge and Valley Physiographic Province. The Glaciated Low Plateau Section is characterized by low to moderately high rounded hills and broad to narrow valleys, all of which have been modified by glacial erosion and deposition. Swamps and peat bogs are common. The Anthracite Valley Section is a narrow to wide, canoe-shaped valley having irregular to linear hills and enclosed by a steep-sloped mountain rim. The southern tip of the county is located in the Glaciated Pocono Plateau Section of the Appalachian Plateaus Physiographic Province, which is characterized by broad, undulatory upland surfaces having dissected margins (Sevon, 2000).

Wayne County is underlain by bedrock of Pennsylvania and Devonian age (figs. 2 and 3). Alluvium and glacial outwash and drift overlie the bedrock. Geologic mapping is more recent and detailed in southern half of the county than in the northern half. Geologic descriptions for bedrock units cropping out in Wayne County are given below.

\section{Catskill Formation (Undifferentiated)}

The Catskill Formation (undifferentiated) of Devonian age underlies the northern half of Wayne County. The Catskill Formation (undifferentiated) consists of a succession of grayish-red sandstone, siltstone, and shale with some gray sandstone and conglomerate. The sandstone layers generally are fine grained and thin bedded (Taylor, 1984). The Catskill Formation in the northern half of Wayne County was mapped by White (1881) and has not been differentiated into the individual members that make up the Catskill Formation. 


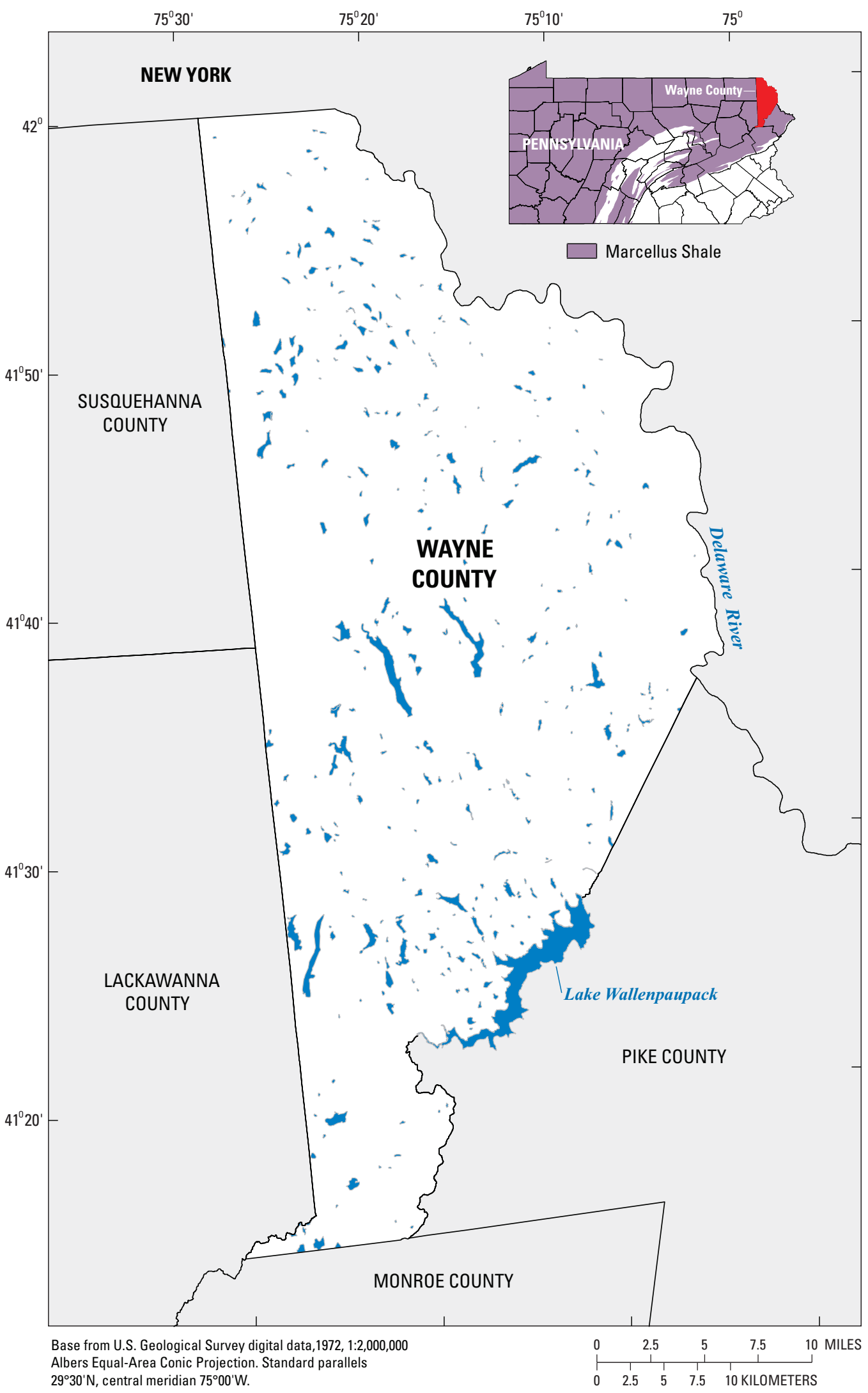

Figure 1. Location of Wayne County, Pennsylvania. 


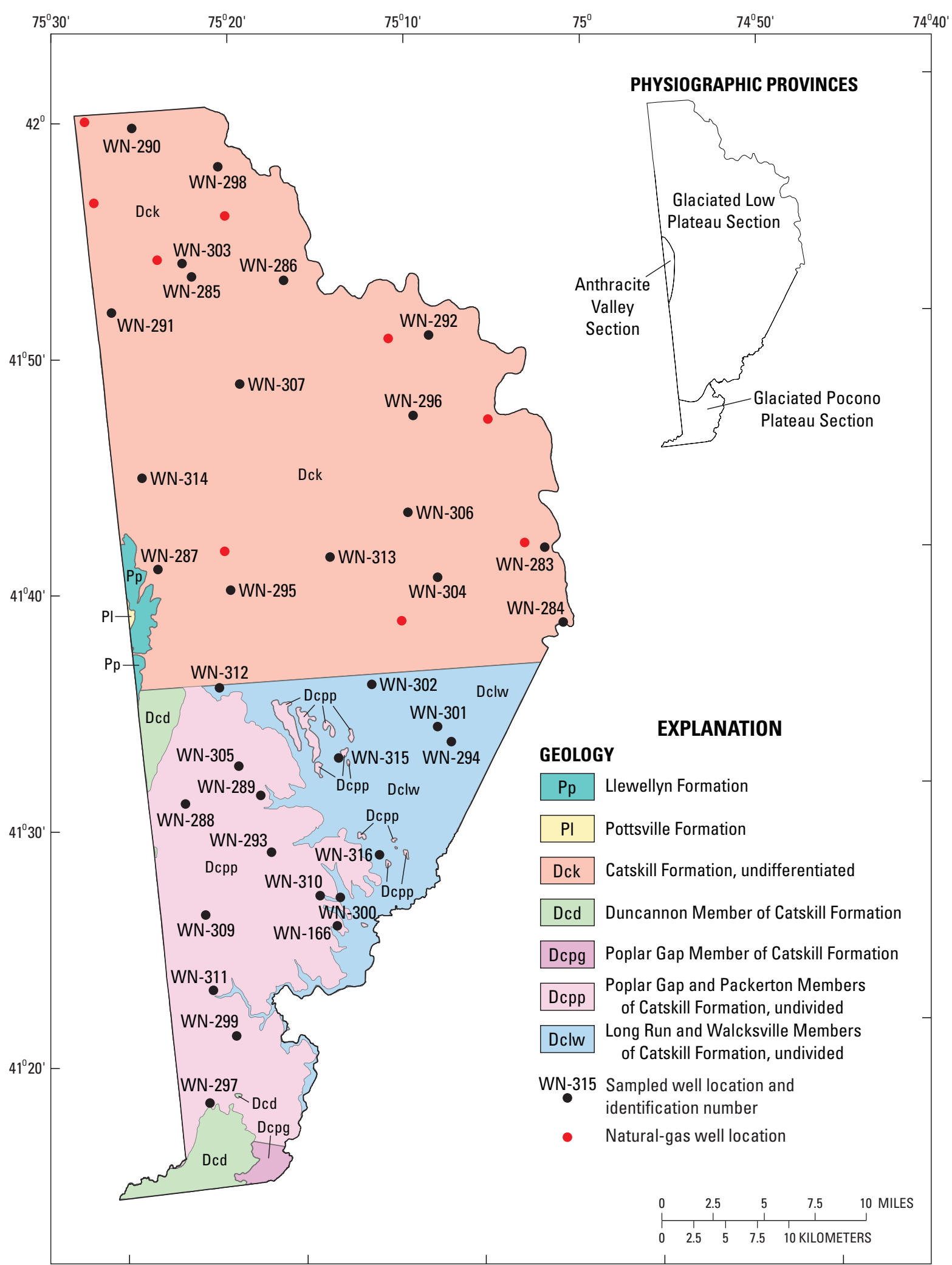

Base from U.S. Geological Survey digital data,1972, 1:2,000,000 Albers Equal-Area Conic Projection. Standard parallels $29^{\circ} 30^{\prime} \mathrm{N}$, central meridian $75^{\circ} 00^{\prime} \mathrm{W}$.

Figure 2. Geology and location of sampled wells, Wayne County, Pennsylvania. 


\section{Long Run and Walcksville Members of Catskill Formation, Undivided}

The Long Run and Walcksville Members are present in southeastern Wayne County. The Long Run Member of the Catskill Formation is a gray, greenish-gray, and grayish-red, cross-bedded to planar-bedded sandstone alternating with grayish-red to greenish-gray siltstone and shale arranged in fining-upward fluvial cycles. The cycles range from 20 to $100 \mathrm{ft}$ thick. The sandstones are blocky, slabby, and sometimes flaggy with hackly and rubbly siltstones and shales. The Long Run Member is about 3,175 ft thick (Berg and others, 1977).

The Walcksville Member of the Catskill Formation is gray and grayish-red sandstones alternating with grayish-red shale in fining-upward fluvial cycles about $15 \mathrm{ft}$ thick. The sandstones are blocky and slabby with chippy, hackly shales. The Walcksville Member is about 1,000 ft thick (Berg and others, 1977).

\section{Poplar Gap and Packerton Members of Catskill Formation, Undivided}

The Poplar Gap Member of the Catskill Formation occurs in southern Wayne County and is a fine- to medium-grained, well-indurated to quartzitic gray sandstone containing some scattered white quartz pebbles as much as 0.5 inch (in.) in diameter. Some sandstone beds have calcareous cementation at the base of the bed. Sandstones grade upward into grayishred siltstones and shales that compose as much as 25 percent of the member. The calculated thickness of the Poplar Gap Member is 1,050 ft (Sevon, 1975).

The Packerton Member of the Catskill Formation is mainly conglomeratic sandstone and sandstone with minor amounts of red shale and siltstone. The conglomeratic sandstone is olive gray to grayish red and weathers to a grayish red. The conglomeratic sandstones generally contain 20 to 40 percent subangular to rounded white quartz pebbles in a

\begin{tabular}{|c|c|c|}
\hline SYSTEM & GEOLOGIC UNIT & LITHOLOGY \\
\hline Quaternary & Alluvium & $\begin{array}{l}\text { Poorly sorted clay, sand, } \\
\text { and gravel }\end{array}$ \\
\hline & Llewellyn Formation & $\begin{array}{l}\text { Sandstone, siltstone, shale, } \\
\text { and some conglomerate } \\
\text { and anthracite coal }\end{array}$ \\
\hline & Pottsville Formation & $\begin{array}{l}\text { Conglomerate, conglomeratic } \\
\text { sandstone, sandstone, } \\
\text { siltstone, and anthracite coal }\end{array}$ \\
\hline & Duncannon Member & Sandstone and conglomerate \\
\hline \multirow{3}{*}{ Devonian } & Poplar Gap Member & Sandstone, siltstone, and shale \\
\hline & $\begin{array}{c}\text { Poplar Gap and Packerton Members, } \\
\text { undivided }\end{array}$ & $\begin{array}{l}\text { Conglomeratic sandstone, } \\
\text { sandstone, and minor } \\
\text { shale and siltstone }\end{array}$ \\
\hline & $\begin{array}{c}\text { Long Run and Walcksville Members, } \\
\text { undivided }\end{array}$ & Sandstone, siltstone, and shale \\
\hline
\end{tabular}

Figure 3. Stratigraphic correlation chart for Wayne County, Pennsylvania. 
medium- to coarse-grained sandstone matrix and range in thickness from 6 in. to $3 \mathrm{ft}$. The calculated thickness of the Packerton Member is $300 \mathrm{ft}$ (Sevon, 1975).

\section{Duncannon Member of Catskill Formation}

The Duncannon Member of the Catskill Formation underlies a small area of the western and southern parts of the county. The Duncannon Member is mainly red and gray sandstone with some red conglomerate. The conglomerate is grayish red and generally has a coarse- to very-coarse-grained sandstone matrix with about 25 to 40 percent pebbles. The conglomerate beds usually are 4 to $6 \mathrm{ft}$ thick and are generally resistant quartzite. The conglomerate grades upward into sandstone. The sandstones are grayish red in the lower part of the member and medium to dark gray in stratigraphically higher parts of the member. The sandstone beds are 2 to $3 \mathrm{ft}$ thick (Sevon, 1975).

\section{Pottsville Formation}

The Pottsville Formation of Pennsylvanian age is of small areal extent in Wayne County; it is present on the far western side of the county. The formation is a gray conglomerate, conglomeratic sandstone, sandstone, and siltstone, with some anthracite coal (Taylor, 1984).

\section{Llewellyn Formation}

The areal extent of the Llewellyn Formation of Pennsylvanian age is small in Wayne County; it is present on the far western side of the county. The formation is a gray, fine- to coarse-grained sandstone, siltstone, and shale with some conglomerate and anthracite coal (Taylor, 1984).

\section{Methods}

Water samples were collected once from 34 domestic wells (table 1 and fig. 2) during August 2011 and August and September 2013 and analyzed to characterize their physical and chemical quality. Samples were analyzed for 45 constituents and properties, including nutrients, major ions, metals, trace elements, radioactivity, and dissolved gases, including methane and radon-222. Three samples (one field blank and two replicate samples) were collected for quality control.

\section{Site Selection}

Two wells were sampled in 2011 as part of a study done in cooperation with the National Park Service (Eckhardt and Sloto, 2012). Selection of the other 32 water wells for sampling was made by the USGS in consultation with the PaGS. Wells were selected from the Pennsylvania Groundwater
Information System database (Pennsylvania Geological Survey, 2014). Only wells with construction data on file were considered. A field reconnaissance was conducted to locate the 32 wells, obtain permission to sample, and verify that any treatment systems could be bypassed. All wells selected for sampling were private domestic wells, ranging in depth from 75 to $1,300 \mathrm{ft}$ (table 1). The wells sampled were representative of the Catskill Formation, undifferentiated, the undivided Poplar Gap and Packerton Members of Catskill Formation, and the undivided Long Run and Walcksville Members of Catskill Formation. No sampled wells were completed in the Llewellyn Formation, Pottsville Formation, or Duncannon Member of the Catskill Formation.

\section{Sampling and Analytical Methods}

Sampling of the two National Park Service wells is described by Eckhardt and Sloto (2012). The USGS and PaGS sampled the other 32 wells using standard USGS fieldsampling protocols. Samples were collected at an untreated tap, typically at a pressure tank or outside tap and before any filtration, water softening, or bacteriological treatment. Water samples were analyzed in the field for physical properties and dissolved oxygen and shipped overnight to laboratories for analysis for major ions, nutrients, metals, trace elements, gross alpha and beta radioactivity, and dissolved gases. The samples were collected from each well and processed for analysis by methods described in USGS manuals for the collection of water-quality data (U.S. Geological Survey, variously dated).

Sampling was done at all well sites using the following steps. The existing submersible well pump was turned on and allowed to run. A raw-water tap was opened, and the water was allowed to flush to ensure that the water was representative of the aquifer. The water was analyzed with a multiprobe meter for physical properties (temperature, specific conductance, and $\mathrm{pH}$ ) and dissolved oxygen concentration. After the values of these physical properties stabilized, pre-rinsed sample bottles were filled according to USGS protocols (U.S. Geological Survey, variously dated). Samples were collected through Teflon tubing attached to the raw-water tap, which avoided all water-treatment systems.

The analyses for physical properties, radioactivity, and dissolved gases were done on unfiltered water samples to obtain total concentrations. Samples for dissolved concentrations of nutrients, major ions, metals, and trace elements were filtered through a pre-rinsed 0.45 -micrometer pore size cellulose capsule filter. To prevent sample degradation, nitric acid was added to the major ion and metals and trace-element samples. Samples for radon analysis were obtained through an inline septum with a gas-tight syringe to avoid atmospheric contact. Samples for dissolved gases were obtained through Teflon tubing placed in bottles that were filled and stoppered while submerged to avoid atmospheric contact.

The samples were stored on ice in coolers and shipped by overnight delivery to the following laboratories: (1) the USGS 
Table 1. Characteristics of 34 wells sampled in Wayne County, Pennsylvania, 2011 and 2013.

[Well locations are shown in figure 2; --, information not available; Dclw, Long Run and Walcksville Members of Catskill Formation, undivided; Dck, Catskill Formation, undifferentiated; Dcpp, Poplar Gap and Packerton Members of Catskill Formation, undivided]

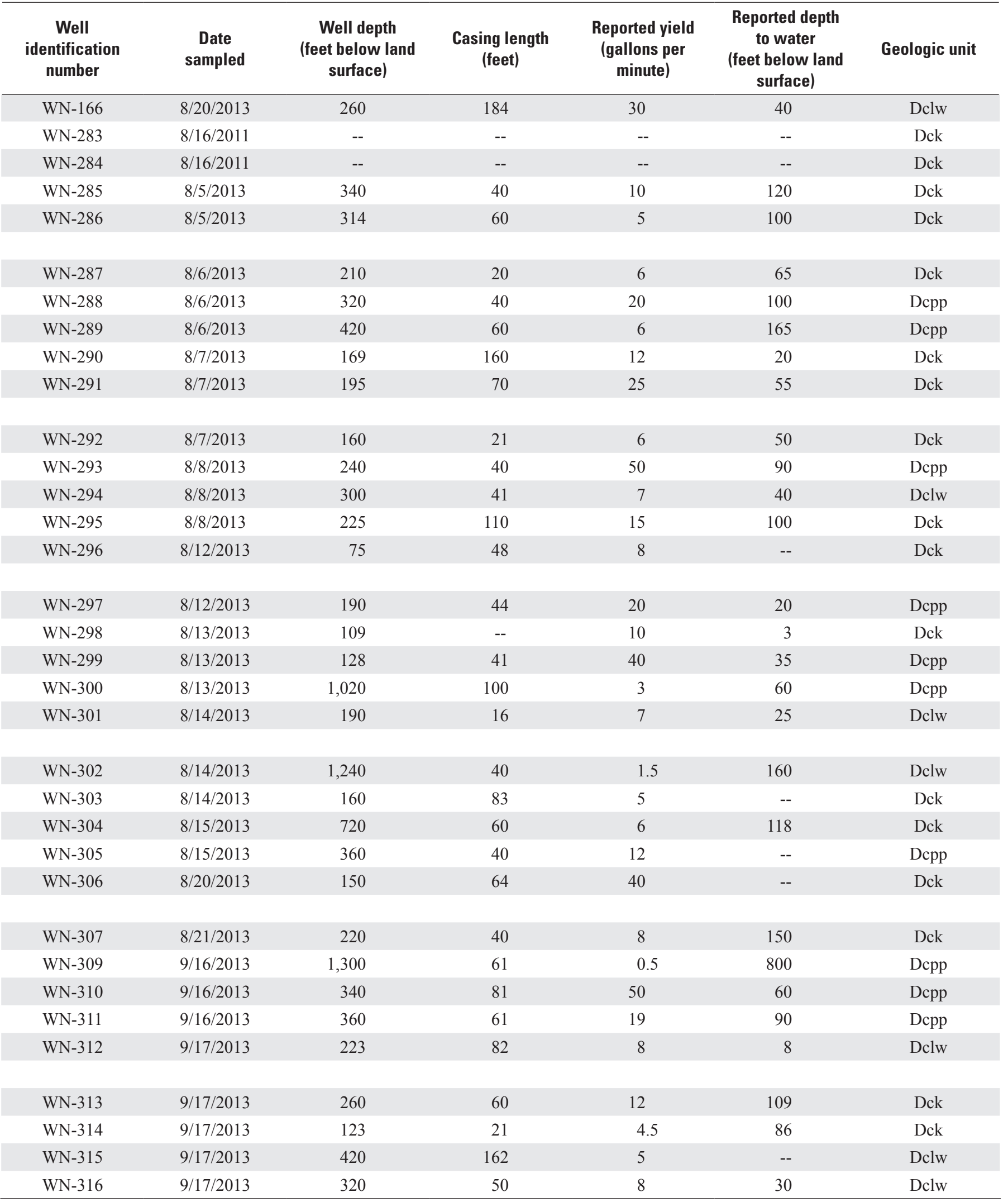


National Water Quality Laboratory in Denver, Colorado, for analysis of major ions, nutrients, metals, trace elements, and radon; (2) a USGS contract laboratory (TestAmerica, Inc.) in Richland, Washington, for analysis of gross alpha and beta radioactivity; and (3) a USGS contract laboratory (Isotech, Inc.) in Champaign, Illinois, for analysis of dissolved methane, other dissolved gases, hydrocarbons, and isotopes of hydrogen and carbon in methane. Dissolved gas amounts were reported in terms of mole percent in headspace for the water sample, and also for methane as a dissolved concentration. Descriptions of analytical methods for constituents analyzed by the USGS National Water Quality Laboratory are available through the U.S. Geological Survey (2014a). The analytical results are available through the USGS National Water Information System (U.S. Geological Survey, 2014b).

Water samples containing a sufficient concentration of methane, generally greater than 0.9 milligrams per liter $(\mathrm{mg} / \mathrm{L})$, were analyzed by a contract laboratory in Champaign, Illinois, for the stable carbon isotopes ${ }^{12} \mathrm{C}$ and ${ }^{13} \mathrm{C}$ and the stable hydrogen isotopes ${ }^{1} \mathrm{H}$ (protium) and ${ }^{2} \mathrm{H}$ (deuterium). For the determination of carbon and hydrogen isotopic ratios for hydrocarbons in a gas mixture, individual hydrocarbons were first separated and then converted into carbon dioxide and water for mass-spectrometric analysis. The hydrocarbons were separated from the water sample by using a gas chromatograph and channeled into a combined combustion-collection unit. The combined combustion-collection unit uses quartz combustion tubes filled with cupric oxide to convert the hydrocarbons into carbon dioxide and water, which are then collected and purified for isotopic analysis.

The carbon dioxide was transferred into Pyrex tubing and sealed for mass spectrometric analysis. The ${ }^{13} \mathrm{C} /{ }^{12} \mathrm{C}$ ratio was determined by a mass spectrometric analysis that compared the sample to a reference standard. The carbon isotope ratio value $\left(\delta^{13} \mathrm{C}\right)$ is reported in terms of per mil (\%o) notation with respect to the Vienna Pee Dee Belemnite (VPDB) standard.

Water samples for hydrogen isotope analysis were sealed into Pyrex tubing along with a measured quantity of zinc. Each sample tube was reacted in a heating block at 500 degrees Celsius $\left({ }^{\circ} \mathrm{C}\right)$ for 35 minutes to generate hydrogen gas. Once the sample had been reacted, the ${ }^{2} \mathrm{H} /{ }^{1} \mathrm{H}$ ratio was determined by mass spectrometric analysis that compared the sample to a reference standard. The hydrogen isotope ratio value $(\delta \mathrm{D})$ is reported in terms of per mil notation with respect to the Vienna Standard Mean Ocean Water (VSMOW) standard (Alan R. Langenfeld, Isotech Laboratories, Inc., written commun., 2012).

\section{Quality Assurance and Quality Control}

For quality control (QC), replicate samples collected from two wells, WN-287 and WN-289, and a field blank were submitted to the laboratories for analysis. The field-blank sample contained two constituents at a concentration greater than the laboratory reporting level. Silica was measured at a concentration of $0.066 \mathrm{mg} / \mathrm{L}$, and gross alpha radioactivity was measured at $0.3 \mathrm{pCi} / \mathrm{L}$ in the blank. The lowest measured concentration of silica in the 34 samples collected in 2013 was $4.46 \mathrm{mg} / \mathrm{L}$; therefore, no corrective action to the analytical results for silica was needed. The lowest measured gross alpha-particle activity in the 34 samples was $0.7 \mathrm{pCi} / \mathrm{L}$. The detection of gross alpha radiation in the blank may be due to laboratory conditions, with the measured activity close to laboratory reporting level of $0.31 \mathrm{pCi} / \mathrm{L}$ and within method uncertainty (table 12 in back of report); therefore, no corrective action to the analytical results for gross alpha activity was needed.

The differences in concentrations between the samples and the replicate samples occurred on the basis of analyte group. For major ions, the difference ranged from -5.5 to 3.6 percent; the median difference was zero. The greatest difference, -5.5 percent, was for potassium. The difference in concentrations between the samples and the replicate samples for metals and trace elements ranged from 23.2 percent for lead to -29 percent for manganese; the median difference was 1.1 percent. The analytes with the largest percent differences in concentrations between the sample and its replicate were low-concentration analytes with the concentrations near the laboratory reporting level. The greatest difference ( 29 percent) was for manganese; the difference in concentrations between the sample $(0.42 \mu \mathrm{g} / \mathrm{L})$ and the replicate sample $(0.30 \mu \mathrm{g} / \mathrm{L})$ was $0.12 \mu \mathrm{g} / \mathrm{L}$. The laboratory detection limit for manganese was $0.15 \mu \mathrm{g} / \mathrm{L}$; therefore, no corrective action to the analytical results was needed, but replicate results show that analytical uncertainty may be relatively greater for constituent concentrations near detection limits.

\section{Baseline Groundwater Quality}

Analytical results for the 34 groundwater samples collected in Wayne County are provided in the following sections. The quality of the sampled groundwater was generally within U.S. Environmental Protection Agency (USEPA) drinking-water standards and, therefore, considered to be very good. However, in some samples, the concentrations of certain constituents exceeded drinking-water standards and health advisories (U.S. Environmental Protection Agency, 2012). The USEPA has set maximum contaminant levels (MCLs) and secondary maximum contaminant levels (SMCLs) for some constituents in drinking water (table 2). MCLs generally are set because elevated concentrations of these constituents may cause adverse health effects. SMCLs generally are set for aesthetic reasons; elevated concentrations of these constituents may impart an undesirable taste or odor to water.

\section{Physical and Chemical Properties}

Physical and chemical properties include temperature, $\mathrm{pH}$, and specific conductance. These properties are unstable 
Table 2. U.S. Environmental Protection Agency maximum contaminant, secondary contaminant, and action levels for constituents in drinking water.

[From U.S. Environmental Protection Agency, 2012; $\mu \mathrm{g} / \mathrm{L}$, micrograms per liter; mg/L, milligrams per liter; pCi/L, picocuries per liter; --, no standard; $\mathrm{N}$, nitrogen]

\begin{tabular}{|c|c|c|c|}
\hline Regulated constituent & Maximum contaminant level & Action level' ${ }^{1}$ & $\begin{array}{c}\text { Secondary maximum } \\
\text { contaminant level }\end{array}$ \\
\hline Aluminum & -- & -- & $50-200 \mu \mathrm{g} / \mathrm{L}$ \\
\hline Arsenic & $10 \mu \mathrm{g} / \mathrm{L}$ & -- & -- \\
\hline Barium & $2,000 \mu \mathrm{g} / \mathrm{L}$ & -- & -- \\
\hline Chromium, total & $100 \mu \mathrm{g} / \mathrm{L}$ & -- & -- \\
\hline Chloride & -- & -- & $250 \mathrm{mg} / \mathrm{L}$ \\
\hline Copper & -- & $1,300 \mu \mathrm{g} / \mathrm{L}$ & $1,000 \mu \mathrm{g} / \mathrm{L}$ \\
\hline Fluoride & $4 \mathrm{mg} / \mathrm{L}$ & -- & $2 \mathrm{mg} / \mathrm{L}$ \\
\hline Nitrate as $\mathrm{N}$ & $10 \mathrm{mg} / \mathrm{L}$ & -- & -- \\
\hline Nitrite & $1 \mathrm{mg} / \mathrm{L}$ & -- & -- \\
\hline $\mathrm{pH}$ & -- & -- & $6.5-8.5$ \\
\hline Selenium & $50 \mu \mathrm{g} / \mathrm{L}$ & -- & -- \\
\hline Silver & -- & -- & $100 \mu \mathrm{g} / \mathrm{L}$ \\
\hline Sulfate & -- & -- & $250 \mathrm{mg} / \mathrm{L}$ \\
\hline Total dissolved solids & -- & -- & $500 \mathrm{mg} / \mathrm{L}$ \\
\hline Uranium & $30 \mu \mathrm{g} / \mathrm{L}$ & -- & -- \\
\hline Zinc & -- & -- & $5,000 \mu \mathrm{g} / \mathrm{L}$ \\
\hline
\end{tabular}

${ }^{1}$ Lead is regulated by a treatment technique that requires water purveyors to control the corrosiveness of their water. If more than 10 percent of tap-water samples exceed the action level, the water purveyor must take additional steps.

and are determined in the field at the time a water sample is collected. Alkalinity and dissolved oxygen concentration also are determined in the field, except for some alkalinity titrations that were conducted in the laboratory. Summary statistics for physical properties are given in table 3 , and field values and analytical results for alkalinity and dissolved methane are provided in table 8 (in back of report).

$\mathrm{pH}$ is a measurement of the activity of hydrogen ions in water. $\mathrm{pH}$ is expressed in logarithmic units with a $\mathrm{pH}$ of 7 considered neutral. Water with a $\mathrm{pH}$ less than 7 is acidic; water with a $\mathrm{pH}$ greater than 7 is basic. The $\mathrm{pH}$ of water samples collected in Wayne County ranged from 5.5 to 9.3 ; the median $\mathrm{pH}$ was 7.0 (table 3 ). The $\mathrm{pH}$ of 14 of the 34 samples (41 percent) was outside the USEPA SMCL range of 6.5 to 8.5 (U.S. Environmental Protection Agency, 2012). Eleven samples had a $\mathrm{pH}$ less than 6.5, and three samples had a $\mathrm{pH}$ greater than 8.5 (table 8 ).
The alkalinity of a solution is a measure of the capacity for the solutes it contains to react with and neutralize acid and commonly consists largely of carbonate and bicarbonate ions (Hem, 1985, p. 106). Alkalinity ranged from 15.4 to $188 \mathrm{mg} / \mathrm{L}$ as calcium carbonate $\left(\mathrm{CaCO}_{3}\right)$; the median concentration was $83.4 \mathrm{mg} / \mathrm{L}$ as $\mathrm{CaCO}_{3}$ (table 3). Alkalinity is related to the $\mathrm{pH}$ of a water sample. In general, water samples with a higher $\mathrm{pH}$ have a higher alkalinity.

Specific conductance is a measurement of the ability of water to conduct an electric current. Specific conductance ranged from 50 to 614 microsiemens per centimeter at 25 degrees Celsius $(\mu \mathrm{S} / \mathrm{cm})$; the median specific conductance was $219 \mu \mathrm{S} / \mathrm{cm}$ (table 3). Specific conductance measured in the 34 water samples is related to the total dissolved solids concentration of the water sample $\left(\mathrm{r}^{2}=0.92\right)$. The mean ratio of total dissolved solids to specific conductance was 0.61 for the 34 water samples. 
Table 3. Summary statistics for physical properties and dissoved oxgen and methane concentrations in groundwater samples collected from 34 wells in Wayne County, Pennsylvania, 2011 and 2013.

[Samples were analyzed for methane by Isotech Laboratories, Inc., Champaign, Illinois; Laboratory alkalinity used where field alkalinity unavailable; n, number of samples; $\mathrm{mg} / \mathrm{L}$, milligrams per liter; $\mu \mathrm{S} / \mathrm{cm}$, microsiemens per centimeter at 25 degrees Celsius; $\mathrm{CaCO}_{3}$, calcium carbonate; <, less than the laboratory detection limit]

\begin{tabular}{|c|c|c|c|c|c|c|c|c|c|c|c|c|}
\hline $\begin{array}{c}\text { Constituent or } \\
\text { property }\end{array}$ & \multicolumn{3}{|c|}{ All wells } & \multicolumn{3}{|c|}{$\begin{array}{c}\text { Catskill Formation, } \\
\text { undifferentiated } \\
\text { (n=17) }\end{array}$} & \multicolumn{3}{|c|}{$\begin{array}{l}\text { Long Run and Walcksville } \\
\text { Members of the Catskill } \\
\text { Formation, undivided } \\
(\mathrm{n}=7)\end{array}$} & \multicolumn{3}{|c|}{$\begin{array}{l}\text { Poplar Gap and Packerton } \\
\text { Members of the Catskill } \\
\text { Formation, undivided } \\
(\mathrm{n}=10)^{1}\end{array}$} \\
\hline $\begin{array}{l}\mathrm{pH}, \text { field } \\
\text { (standard } \\
\text { units) }\end{array}$ & 5.5 & 7.0 & 9.3 & 5.5 & 6.5 & 9.2 & 5.9 & 6.7 & 7.8 & 5.5 & 7.3 & 9.3 \\
\hline $\begin{array}{c}\text { Specific } \\
\text { conductance, } \\
\text { field } \\
(\mu \mathrm{S} / \mathrm{cm})\end{array}$ & 50 & 219 & 614 & 50 & 180 & 614 & 90 & 223 & 247 & 86 & 245 & 544 \\
\hline $\begin{array}{l}\text { Oxygen, } \\
\text { dissolved, } \\
\text { field } \\
(\mathrm{mg} / \mathrm{L})\end{array}$ & 0.2 & 4.7 & 11.5 & 0.3 & 5.9 & 10.1 & 0.2 & 4.3 & 6.2 & 0.2 & 4.8 & 11.5 \\
\hline $\begin{array}{l}\text { Methane, } \\
\text { dissolved } \\
(\mathrm{mg} / \mathrm{L})\end{array}$ & $<0.00006$ & 0.00019 & 3.3 & $<0.00006$ & 0.00013 & 3.3 & $<0.00006$ & 0.00057 & 0.04 & $<0.00006$ & 0.00013 & 0.93 \\
\hline
\end{tabular}

${ }^{1} \mathrm{n}=8$ for dissolved oxygen.

Dissolved oxygen concentrations ranged from 0.2 to $11.5 \mathrm{mg} / \mathrm{L}$; the median concentration was $4.7 \mathrm{mg} / \mathrm{L}$ (table 3 ). The dissolved oxygen concentration was less than $1 \mathrm{mg} / \mathrm{L}$ in water samples from six wells (table 8). Low dissolved oxygen concentrations are associated with higher $\mathrm{pH}$ values; 5 of the 6 water samples with a dissolved oxygen concentration less than $1 \mathrm{mg} / \mathrm{L}$ had a $\mathrm{pH}$ greater than 7.7 (fig. 4). Low dissolved oxygen concentrations are related to chemical or biochemical reactions that consume oxygen and may be associated with reducing conditions that promote the release of some metals. The chemical reactions that consume oxygen can be naturally occurring in soil or aquifer materials. Median dissolved oxygen concentrations ranged from $4.3 \mathrm{mg} / \mathrm{L}$ for the Long Run and Walcksville Members to $5.9 \mathrm{mg} / \mathrm{L}$ for the Catskill Formation, undifferentiated (table 3).

\section{Dissolved Methane and Other Hydrocarbon Gases}

Water samples were analyzed for the hydrocarbon gases methane, ethane, ethylene, propane, propylene, iso-butane, and N-butane and for the hydrocarbon liquids iso-pentane,
$\mathrm{N}$-pentane, and hexane. Only methane and ethane were detected; the other hydrocarbons were not detected.

Summary statistics for methane are given in table 3 , and analytical results for methane and ethane are provided in table 8 (in back of report). Ethane concentrations were not determined but its presence can be verified, and the relative amount of dissolved ethane can be estimated by the laboratory reported units of mole percent. Ethane was detected in the four water samples with methane concentrations greater than $0.08 \mathrm{mg} / \mathrm{L}$ (table 8 ).

Methane was detectable in 22 of the 34 samples (65 percent) (table 8). Concentrations of dissolved methane for all 34 wells ranged from less than 0.00006 to $3.3 \mathrm{mg} / \mathrm{L}$; the median concentration was $0.00019 \mathrm{mg} / \mathrm{L}$ (table 3 ). None of the dissolved methane concentrations exceeded the Pennsylvania action level of $7 \mathrm{mg} / \mathrm{L}$ (Commonwealth of Pennsylvania, 2014). Methane concentrations were greatest in water samples with $\mathrm{pH}$ of 7.8 or higher, ranging from 0.04 to $3.3 \mathrm{mg} / \mathrm{L}$ in 5 of the 22 water samples in which it was detected (fig. 5). These 5 samples also had among the lowest concentrations of dissolved oxygen (less than or equal to $0.5 \mathrm{mg} / \mathrm{L}$ ). 


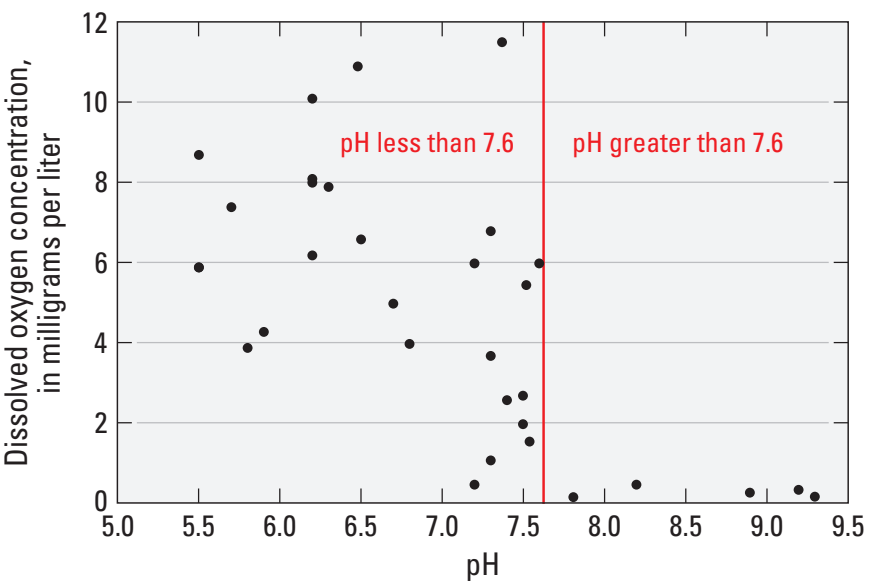

Figure 4. Relation between $\mathrm{pH}$ and dissolved oxygen concentration in groundwater samples collected from 34 wells in Wayne County, Pennsylvania.

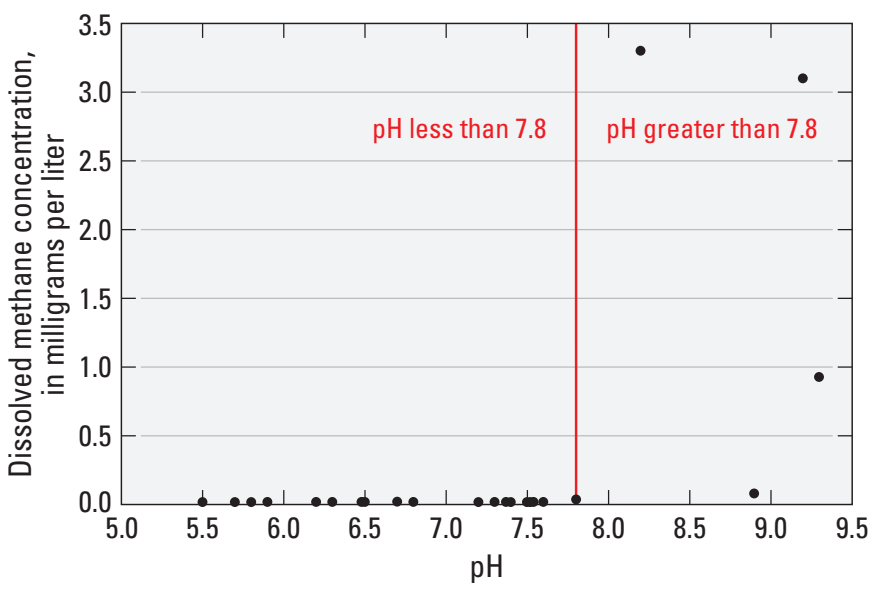

Figure 5. Relation between $\mathrm{pH}$ and dissolved methane concentration in groundwater samples collected from 34 wells in Wayne County, Pennsylvania.

Water samples with methane concentrations equal to or greater than $0.04 \mathrm{mg} / \mathrm{L}$ (and $\mathrm{pH}$ greater than or equal to 7.8) had relatively elevated concentrations of arsenic, boron, bromide, fluoride, iron, lithium, and sodium. All five water samples with methane concentrations equal to or greater than $0.04 \mathrm{mg} / \mathrm{L}$ (table 8 ) had the highest lithium concentrations (table 11). Four of the five water samples with methane concentrations equal to or greater than $0.04 \mathrm{mg} / \mathrm{L}$ had the highest concentrations of arsenic, boron, bromide, fluoride, and sodium. Water samples with methane concentrations equal to or greater than $0.04 \mathrm{mg} / \mathrm{L}$ also had higher than median concentrations of manganese, molybdenum, and total dissolved solids (tables 9 and 11).

Three water samples (WN-295, WN-298, and WN-309), which had sufficient dissolved methane concentrations (greater than $0.9 \mathrm{mg} / \mathrm{L}$ ), were analyzed for isotopes of carbon and hydrogen in the methane. The $\delta^{13} \mathrm{C}$ values ranged from -60.32 to -53.96 per mil, and the $\delta \mathrm{D}$ values ranged from -193.8 to -180.0 per mil. The values for methane in samples from wells WN-295 and WN-298 fall within the range for a thermogenic natural gas source (fig. 6). The values for methane in samples from well WN-309 fall in the area between a thermogenic and a microbial (biogenic) gas source, indicating that it probably is a mixture from both sources (fig. 6). Water samples from these three wells also had detectable ethane concentrations (table 8). The presence of ethane may be an indicator of a thermogenic source for methane; methane/ethane ratios are sometimes used to infer the source of gas (Taylor and others, 2000).

\section{Major Ions}

Major ions dissolved from soil and rock contribute most of the naturally occurring dissolved solutes in groundwater; the remainder comes mostly from constituents dissolved in precipitation. The major ions generally account for most of the dissolved constituents in groundwater. The major ions consist of positively charged cations (calcium, magnesium, sodium, and potassium) balanced by negatively charged anions (bicarbonate, chloride, nitrate, sulfate, and fluoride). Silica is a major constituent that commonly occurs as an uncharged ion. Summary statistics for major ions are given in table 4, and analytical results are provided in table 9 (in back of report). Major ions, in order of decreasing median concentration, were calcium, sodium, silica, sulfate, chloride, magnesium, potassium, fluoride, and bromide.

Total dissolved solids is a measurement of the total solutes in water; it is measured by evaporating the water and weighing the residue. The total dissolved solids concentration ranged from 33 to $346 \mathrm{mg} / \mathrm{L}$; the median concentration was $126 \mathrm{mg} / \mathrm{L}$. Median total dissolved solids concentrations ranged from $102 \mathrm{mg} / \mathrm{L}$ for wells in the Catskill Formation, undifferentiated, to $136 \mathrm{mg} / \mathrm{L}$ for wells in the Poplar Gap and Packerton Members (table 4).

Sodium concentrations ranged from 1.07 to $116 \mathrm{mg} / \mathrm{L}$; the median concentration was $9.42 \mathrm{mg} / \mathrm{L}$. Median sodium concentrations ranged from $8.43 \mathrm{mg} / \mathrm{L}$ in the Catskill Formation, undifferentiated, to $11.4 \mathrm{mg} / \mathrm{L}$ in the Poplar Gap and Packerton Members (table 4). The USEPA has issued a health advisory for sodium in public water supplies (U.S. Environmental Protection Agency, 2003). The advisory states, "This Advisory recommends reducing sodium concentrations in drinking water to between 30 and $60 \mathrm{mg} / \mathrm{L}$ based on esthetic effects (i.e., taste). This recommendation is not federally enforceable but is intended as a guideline for States. Drinking water containing between 30 and $60 \mathrm{mg} / \mathrm{L}$ is unlikely to be perceived as salty by most individuals and would contribute only 2.5 percent to 5 percent of the dietary goal if tap water consumption is $2 \mathrm{~L} /$ day. At the present time the USEPA guidance level for sodium in drinking water is $20 \mathrm{mg} / \mathrm{L}$. This value was developed for those individuals restricted to a total sodium intake 


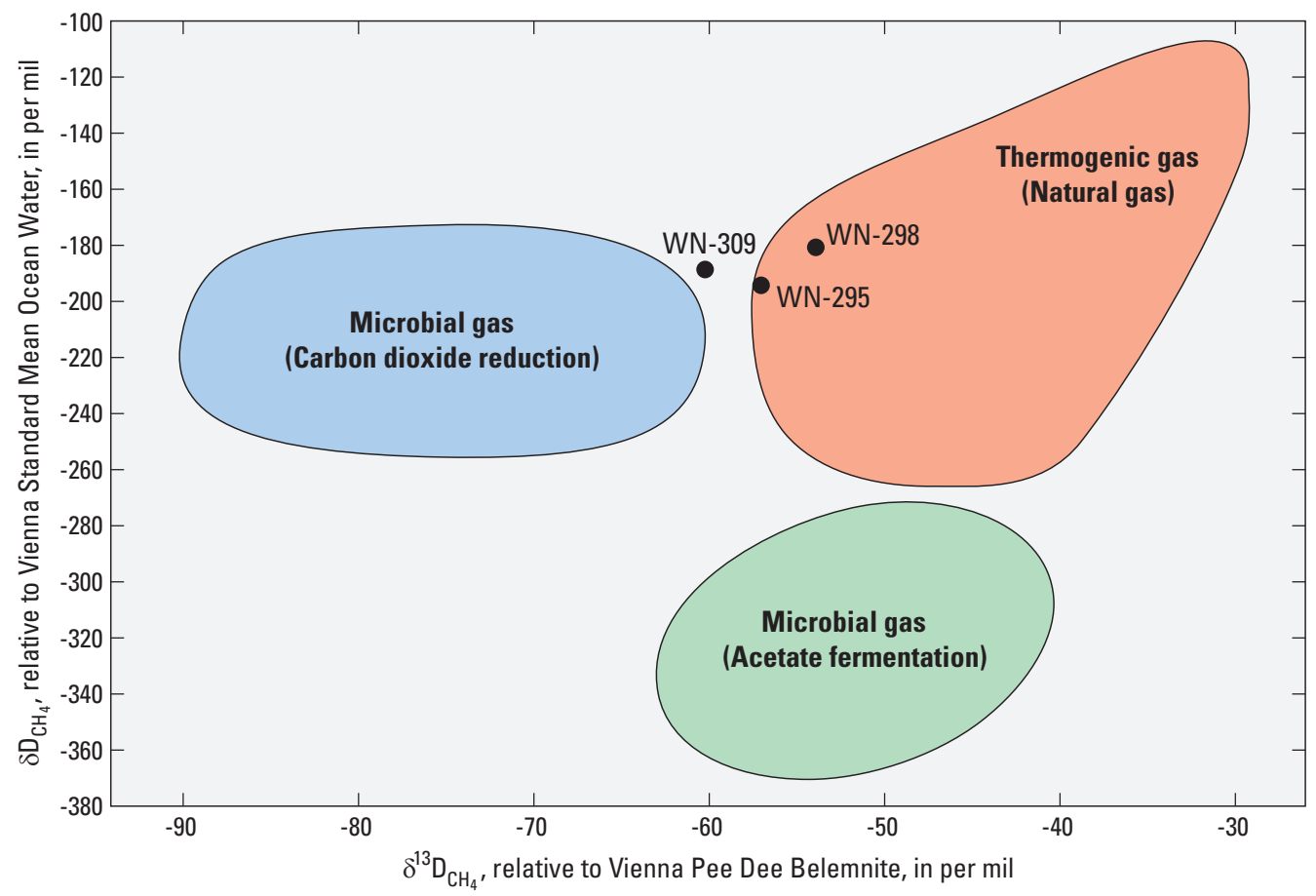

Figure 6. Stable isotopic composition of carbon and hydrogen in dissolved methane in three groundwater samples from Wayne County, Pennsylvania. Diagram shows process end members observed in natural systems (Modified from Coleman and others, 1993, based on the dataset of Schoell, 1980). Isotope analyses were done by Isotech Laboratories, Inc. in Champaign, Illinois.

Table 4. Summary statistics for concentrations of major ions in groundwater samples collected from 34 wells in Wayne County, Pennsylvania, 2011 and 2013.

[All constituent concentrations are in milligrams per liter; $\mathrm{n}$, number of samples; <, less than the laboratory detection limit; E, estimated concentration]

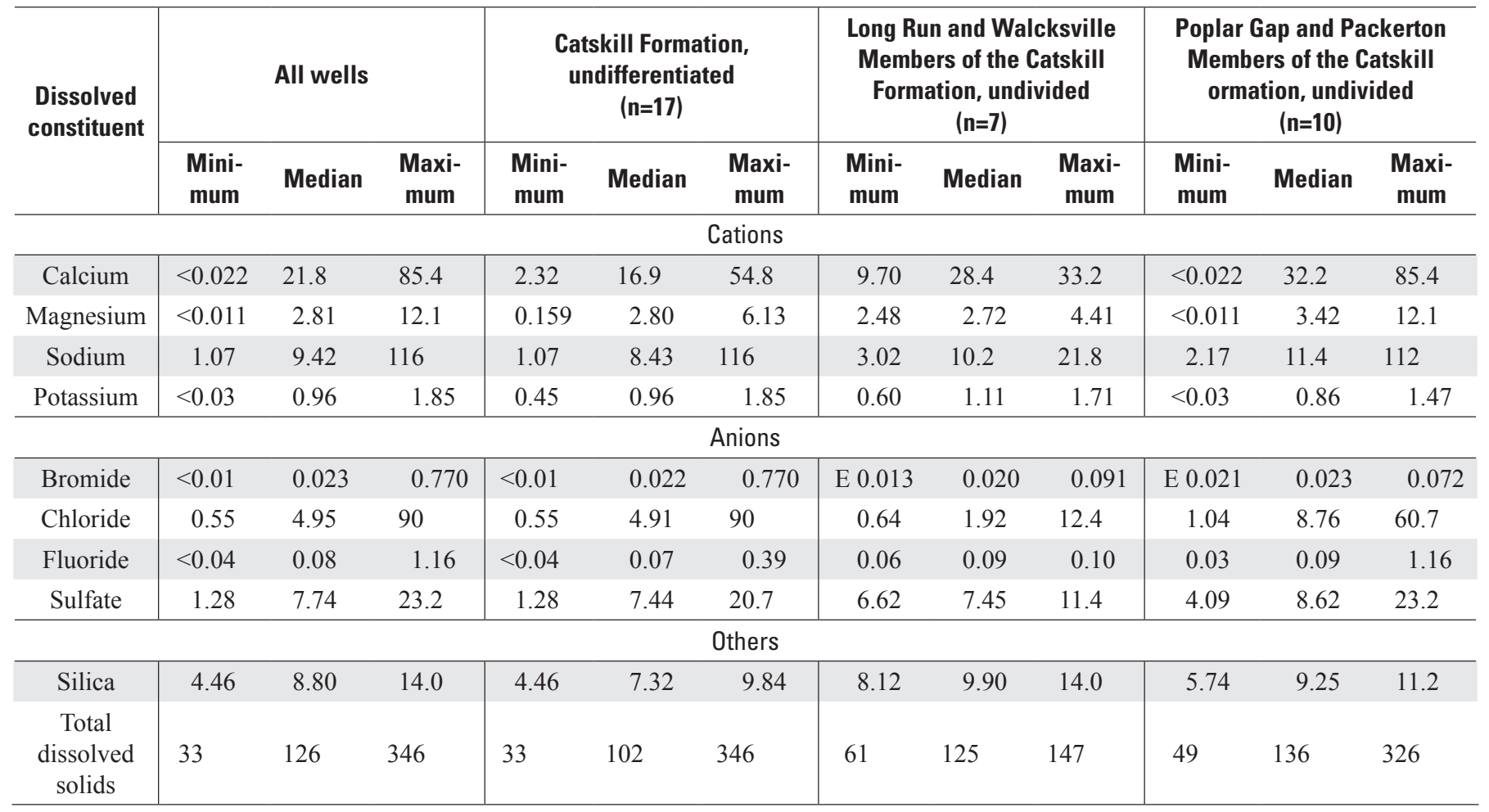


of $500 \mathrm{mg}$ /day and should not be extrapolated to the entire population." The sodium concentration exceeded $20 \mathrm{mg} / \mathrm{L}$ in 7 of the 34 water samples ( 21 percent).

Chloride concentrations ranged from 0.55 to $90 \mathrm{mg} / \mathrm{L}$; the median concentration was $4.95 \mathrm{mg} / \mathrm{L}$. Median chloride concentrations ranged from $1.92 \mathrm{mg} / \mathrm{L}$ in the Long Run and Walcksville Members to $8.76 \mathrm{mg} / \mathrm{L}$ in the Poplar Gap and Packerton Members (table 4).

\section{Nutrients}

Nutrients include nitrogen and phosphorus species. Nitrogen is found in water principally as nitrate $\left(\mathrm{NO}_{3}\right)$, nitrite $\left(\mathrm{NO}_{2}\right)$, and ammonia $\left(\mathrm{NH}_{4}\right)$. Nutrients are essential for plant growth; however, the presence of elevated nutrient concentrations generally is an indicator of an anthropogenic source(s) of nitrogen, which in groundwater might include fertilizers, storm runoff, animal wastes, and effluent from septic systems. Summary statistics for nutrients are given in table 5 , and analytical results are provided in table 10 (in back of report). Concentrations of nutrients in samples from the 34 wells were low. Nitrite, ammonia, and orthophosphate, when detected, were present in concentrations less than $0.1 \mathrm{mg} / \mathrm{L}$ as nitrogen (N). Median concentrations of ammonia (less than $0.01 \mathrm{mg} / \mathrm{L}$ as $\mathrm{N}$ ) and nitrite (less than $0.001 \mathrm{mg} / \mathrm{L}$ as $\mathrm{N}$ ) were less than the laboratory detection limit. The median concentration of orthophosphate was $0.016 \mathrm{mg} / \mathrm{L}$ as phosphorus (P).
Nitrate is the most prevalent nitrogen species in groundwater (table 5). Because concentrations of nitrite are so low, nitrate plus nitrite concentrations essentially represent nitrate concentrations. The concentration of nitrate ranged from less than 0.04 to $2.75 \mathrm{mg} / \mathrm{L}$ as $\mathrm{N}$; the median concentration was $0.632 \mathrm{mg} / \mathrm{L}$ as $\mathrm{N}$. All nitrate concentrations were less than the USEPA MCL of $10 \mathrm{mg} / \mathrm{L}$ for nitrate as N.

\section{Metals and Trace Elements}

Metals and other trace elements typically are present in concentrations less than $1 \mathrm{mg} / \mathrm{L}$ in natural waters (Hem, 1985). Most of the metals and trace elements in groundwater are leached from the soil or dissolved from the underlying bedrock in minute quantities by groundwater. Some are present in precipitation.

Summary statistics for metals and trace elements are listed in table 6 , and analytical results are provided in table 11 (in back of report). The USEPA has established MCLs and SMCLs for some of these constituents in drinking water (table 2). Of these constituents, two samples exceeded the USEPA MCL for arsenic, and one sample exceeded the USEPA SMCL for manganese (table 11). Manganese concentrations were less than the USEPA lifetime health advisory of $300 \mu \mathrm{g} / \mathrm{L}$ (U.S. Environmental Protection Agency, 2004).

Concentrations of dissolved arsenic in water from the 34 sampled wells ranged from 0.06 to $21.8 \mu \mathrm{g} / \mathrm{L}$; the median

Table 5. Summary statistics for concentrations of nutrients in groundwater samples collected from 34 wells in Wayne County, Pennsylvania, 2011 and 2013.

[All constituents are in milligrams per liter; n, number of samples; N, nitrogen; P, phosphorus; <, less than the laboratory detection limit]

\begin{tabular}{|c|c|c|c|c|c|c|c|c|c|c|c|c|}
\hline \multirow[t]{2}{*}{$\begin{array}{l}\text { Dissolved } \\
\text { constituent }\end{array}$} & \multicolumn{3}{|c|}{ All wells } & \multicolumn{3}{|c|}{$\begin{array}{l}\text { Catskill Formation, } \\
\text { undifferentiated } \\
\qquad(\mathrm{n}=17)\end{array}$} & \multicolumn{3}{|c|}{$\begin{array}{l}\text { Long Run and Walcksville } \\
\text { Members of the Catskill } \\
\text { Formation, undivided } \\
(\mathrm{n}=7)\end{array}$} & \multicolumn{3}{|c|}{$\begin{array}{l}\text { Poplar Gap and Packerton } \\
\text { Members of the Catskill } \\
\text { Formation, undivided } \\
(\mathbf{n}=10)\end{array}$} \\
\hline & $\begin{array}{l}\text { Mini- } \\
\text { mum }\end{array}$ & Median & $\begin{array}{l}\text { Maxi- } \\
\text { mum }\end{array}$ & $\begin{array}{l}\text { Mini- } \\
\text { mum }\end{array}$ & Median & $\begin{array}{c}\text { Maxi- } \\
\text { mum }\end{array}$ & $\begin{array}{l}\text { Mini- } \\
\text { mum }\end{array}$ & Median & $\begin{array}{c}\text { Maxi- } \\
\text { mum }\end{array}$ & $\begin{array}{l}\text { Mini- } \\
\text { mum }\end{array}$ & Median & $\begin{array}{r}\text { Maxi- } \\
\text { mum }\end{array}$ \\
\hline $\begin{array}{l}\text { Ammonia, } \\
\text { dissolved } \\
\text { (as N) }\end{array}$ & $<0.01$ & $<0.01$ & 0.094 & $<0.01$ & $<0.01$ & 0.094 & $<0.01$ & $<0.01$ & 0.013 & $<0.01$ & $<0.01$ & $<0.01$ \\
\hline $\begin{array}{l}\text { Nitrate } \\
\text { plus nitrite, } \\
\text { dissolved } \\
\text { (as N) }\end{array}$ & $<0.04$ & 0.632 & 2.75 & $<0.04$ & 0.648 & 1.16 & $<0.04$ & 0.085 & 1.75 & 0.077 & 0.674 & 2.75 \\
\hline $\begin{array}{l}\text { Nitrite, } \\
\text { dissolved } \\
\text { (as N) }\end{array}$ & $<0.001$ & $<0.001$ & 0.055 & $<0.001$ & $<0.001$ & 0.055 & $<0.001$ & $<0.001$ & $<0.001$ & $<0.001$ & $<0.001$ & 0.043 \\
\hline $\begin{array}{l}\text { Orthophosphate, } \\
\text { dissolved } \\
\text { (as P) }\end{array}$ & 0.005 & 0.016 & 0.043 & 0.005 & 0.017 & 0.043 & 0.005 & 0.013 & 0.025 & 0.008 & 0.022 & 0.028 \\
\hline
\end{tabular}


Table 6. Summary statistics for concentrations of metals and trace elements in groundwater samples collected from 34 wells in Wayne County, Pennsylvania, 2011 and 2013.

[All concentrations are in micrograms per liter; $n$, number of samples; <, less than the laboratory detection limit; E, estimated concentration; --, unable to calculate statistic]

\begin{tabular}{|c|c|c|c|c|c|c|c|c|c|c|c|c|}
\hline \multirow[t]{2}{*}{$\begin{array}{l}\text { Dissolved } \\
\text { constituent }\end{array}$} & \multicolumn{3}{|c|}{ All wells } & \multicolumn{3}{|c|}{$\begin{array}{l}\text { Catskill Formation, } \\
\text { undifferentiated } \\
(\mathrm{n}=17)\end{array}$} & \multicolumn{3}{|c|}{$\begin{array}{l}\text { Long Run and Walcksville } \\
\text { Members of the Catskill } \\
\text { Formation, undivided } \\
\qquad(\mathrm{n}=7)\end{array}$} & \multicolumn{3}{|c|}{$\begin{array}{l}\text { Poplar Gap and Packerton } \\
\text { Members of the Catskill } \\
\text { Formation, undivided } \\
(\mathbf{n}=10)\end{array}$} \\
\hline & $\begin{array}{c}\text { Mini- } \\
\text { mum }\end{array}$ & Median & $\begin{array}{c}\text { Maxi- } \\
\text { mum }\end{array}$ & $\begin{array}{c}\text { Mini- } \\
\text { mum }\end{array}$ & Median & $\begin{array}{c}\text { Maxi- } \\
\text { mum }\end{array}$ & $\begin{array}{l}\text { Mini- } \\
\text { mum }\end{array}$ & Median & $\begin{array}{c}\text { Maxi- } \\
\text { mum }\end{array}$ & $\begin{array}{c}\text { Mini- } \\
\text { mum }\end{array}$ & Median & $\begin{array}{c}\text { Maxi- } \\
\text { mum }\end{array}$ \\
\hline Aluminum & $<2.2$ & $<2.2$ & 104 & $<2.2$ & $<2.2$ & 46.6 & $<2.2$ & $<2.2$ & $<2.2$ & $<2.2$ & $<2.2$ & 104 \\
\hline Arsenic & 0.06 & 0.59 & 21.8 & 0.06 & 0.49 & 20.9 & 0.41 & 1.0 & 6.3 & 0.15 & 0.53 & 21.8 \\
\hline Barium & $<0.1$ & 72.1 & 842 & 9.18 & 70.0 & 842 & 5.85 & 173 & 366 & $<0.1$ & 62.0 & 162 \\
\hline Beryllium & $<0.006$ & $<0.006$ & 0.030 & $<0.006$ & $<0.006$ & 0.010 & $<0.006$ & $<0.006$ & 0.030 & $<0.006$ & $<0.006$ & 0.029 \\
\hline Boron & $<3$ & 10 & 165 & $<3$ & 9 & 107 & 4 & 12 & 33 & 4 & 8 & 165 \\
\hline Cadmium & $<0.016$ & $<0.016$ & 0.033 & $<0.016$ & $<0.016$ & 0.021 & $<0.016$ & $<0.016$ & 0.033 & $<0.016$ & $<0.016$ & 0.028 \\
\hline Iron & $<3$ & $<4$ & 223 & $<3$ & $<4$ & 223 & $<4$ & $<4$ & 17.2 & $<4$ & $<4$ & 31.4 \\
\hline Lead & $<0.05$ & 0.212 & 1.74 & $<0.05$ & 0.163 & 1.74 & $<0.025$ & 0.495 & 0.570 & 0.084 & 0.181 & 1.20 \\
\hline Lithium $^{1}$ & 0.07 & E 11.2 & 519 & E 1.20 & E 5.48 & E 411 & 6.90 & 12.9 & 67.5 & 0.07 & E 10.3 & 519 \\
\hline Manganese & $<0.15$ & 0.42 & 61.5 & $<0.15$ & 0.42 & 46.9 & $<0.15$ & 1.86 & 61.5 & $<0.15$ & 0.21 & 6.69 \\
\hline Molybdenum & $<0.014$ & 0.11 & 1.26 & $<0.014$ & 0.11 & 1.26 & $<0.014$ & 0.162 & 0.45 & $<0.014$ & 0.071 & 0.78 \\
\hline Nickel & $<0.09$ & 0.22 & 0.87 & $<0.09$ & 0.17 & 0.68 & 0.12 & 0.26 & 0.71 & $<0.09$ & 0.26 & 0.87 \\
\hline Selenium & $<0.03$ & 0.11 & 0.57 & 0.03 & 0.07 & 0.20 & $<0.03$ & 0.11 & 0.57 & $<0.03$ & 0.17 & 0.26 \\
\hline Silver & $<0.005$ & $<0.005$ & 0.009 & $<0.005$ & $<0.005$ & 0.009 & $<0.005$ & $<0.005$ & $<0.005$ & $<0.005$ & $<0.005$ & $<0.005$ \\
\hline
\end{tabular}

${ }^{1}$ Estimated values treated as unestimated for statistical analysis.

concentration was $0.59 \mu \mathrm{g} / \mathrm{L}$ (table 6). Median arsenic concentrations ranged from $0.49 \mu \mathrm{g} / \mathrm{L}$ for the Catskill Formation, undifferentiated, to $1 \mu \mathrm{g} / \mathrm{L}$ for the Long Run and Walcksville Members. Water samples from 2 of the 34 wells (6 percent) exceeded the USEPA MCL of $10 \mu \mathrm{g} / \mathrm{L}$ for arsenic; one well is in the Catskill Formation, undifferentiated, and one well is in the Poplar Gap and Packerton Members. The concentration of arsenic $(9.92 \mu \mathrm{g} / \mathrm{L})$ in water from one well in the Catskill Formation, undifferentiated, was slightly less than the USEPA MCL.

Arsenic concentration is related to $\mathrm{pH}$ (fig. 7). The three water samples with arsenic concentrations exceeding $9 \mu \mathrm{g} / \mathrm{L}$ had a $\mathrm{pH}$ greater than 8.2. Arsenate $\left(\mathrm{AsO}_{4}{ }^{3-}\right)$ and arsenite [As(III)] adsorb to surfaces of a variety of aquifer materials, including iron oxides, aluminum oxides, and clay minerals.
Arsenate adsorbs strongly to iron-oxide surfaces in acidic and near-neutral pH water; however, desorption of arsenate from iron-oxide surfaces becomes favored as $\mathrm{pH}$ values become alkaline (Dzombak and Morel, 1990). The $\mathrm{pH}$ dependence of arsenate adsorption to iron-oxide surfaces appears to be related to the change in iron-oxide net surface charge from positive to negative as $\mathrm{pH}$ increases above the zero point of charge $(\mathrm{pH}$ at which the net surface charge is equal to zero) to about 7.7 for goethite (crystalline iron oxide) (Stumm and Morgan, 1996) or 8.0 for ferrihydrite (amorphous iron oxide) (Dzombak and Morel, 1990). Where $\mathrm{pH}$ values are greater than about 8 , the negative net surface charge of iron oxide can repel negatively charged ions, such as arsenate.

Water samples with a $\mathrm{pH}$ of 7.8 or greater also had relatively elevated concentrations of boron (fig. 8), bromide 


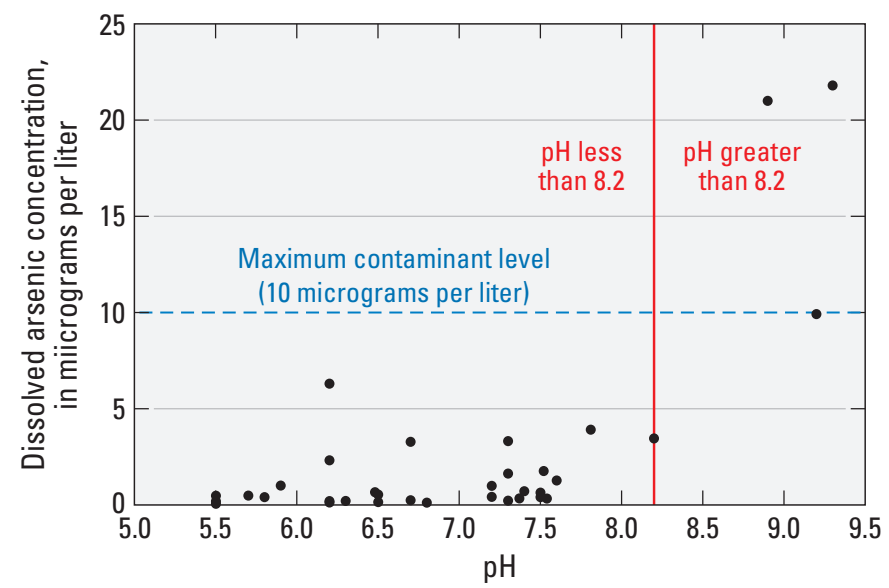

Figure 7. Relation between $\mathrm{pH}$ and arsenic concentration in groundwater samples collected from 34 wells in Wayne County, Pennsylvania.

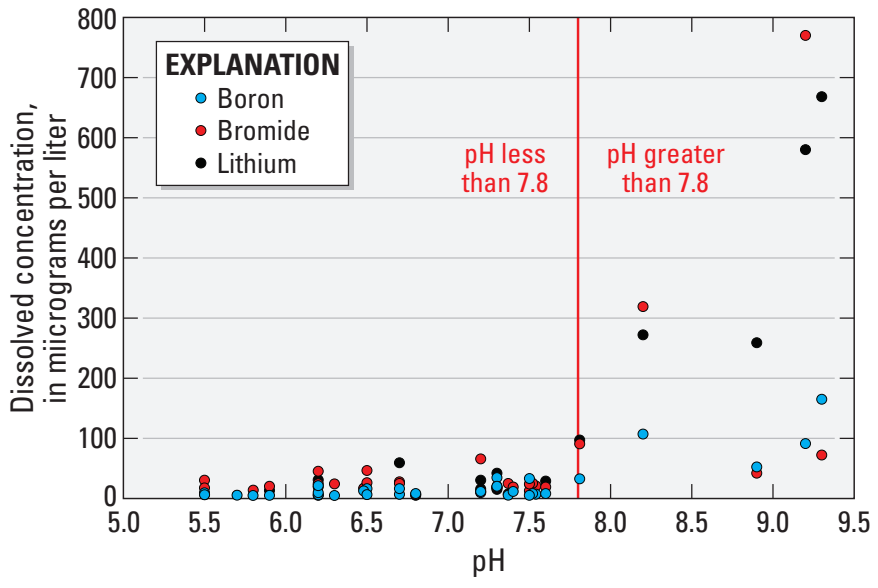

Figure 8. Relation between $\mathrm{pH}$ and boron, bromide, and lithium concentrations in groundwater samples collected from 34 wells in Wayne County, Pennsylvania.

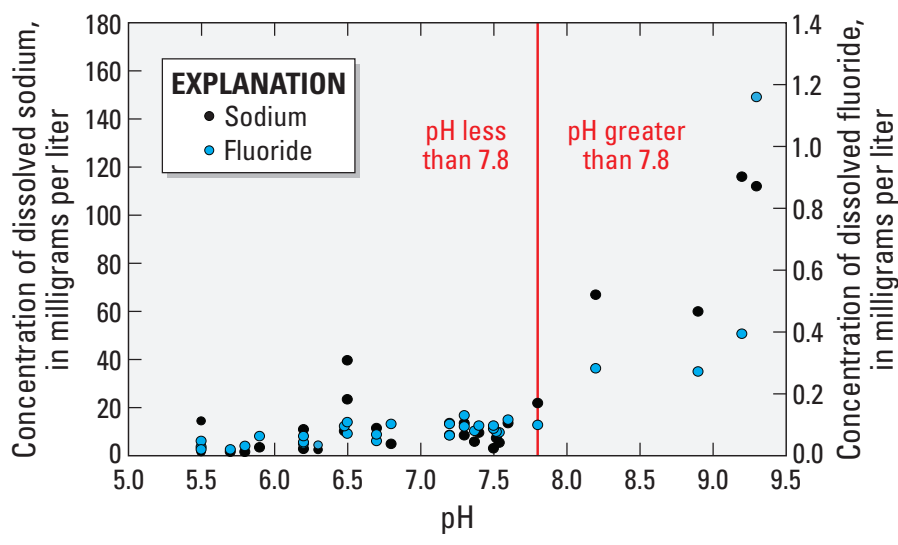

Figure 9. Relation between $\mathrm{pH}$ and fluoride and sodium concentrations in groundwater samples collected from 34 wells in Wayne County, Pennsylvania. (fig. 8), fluoride (fig. 9), lithium (fig. 8), and sodium (fig. 9). In addition, water samples with a $\mathrm{pH}$ greater than 7.6 had low concentrations of copper, nickel, and zinc. For these elements, the reduced form is less soluble than the oxidized form, and they tend to be insoluble under reducing conditions (higher $\mathrm{pH}$ waters). All 5 water samples with a $\mathrm{pH}$ greater than $7.6 \mathrm{had}$ copper and zinc concentrations less than the detection limit, and 3 of the 5 water samples had nickel concentrations less than the detection limit.

Concentrations of dissolved manganese in water from the 34 wells ranged from less than 0.15 to $61.5 \mu \mathrm{g} / \mathrm{L}$; the median concentration was $0.42 \mu \mathrm{g} / \mathrm{L}$ (table 6). Median manganese concentrations ranged from $0.21 \mu \mathrm{g} / \mathrm{L}$ for the Poplar Gap and Packerton Members to $1.86 \mu \mathrm{g} / \mathrm{L}$ for the Long Run and Walcksville Members. Water samples from 1 of the 34 wells (3 percent) exceeded the USEPA SMCL of $50 \mu \mathrm{g} / \mathrm{L}$ for manganese; the well is in the Long Run and Walcksville Members.

\section{Radionuclides}

Radionuclides naturally present in rocks and soils may be dissolved or leached into groundwater. Analyses for radioactivity and radionuclides included gross alpha radioactivity, gross beta radioactivity, and dissolved radon-222 (radon gas). Uranium, a radioactive element, also was analyzed in the dissolved form. Summary statistics for radioactive constituents are given in table 7, and analytical results are provided in table 12 (in back of report). The USEPA has established or proposed MCLs for some of these constituents in drinking water (table 2).

Radioactivity is the release of energy and energetic particles by changes in the structure of certain unstable elements as they break down to form more stable arrangements. Radioactive energy is released as (1) alpha radiation consisting of positively charged helium nuclei, (2) beta radiation consisting of electrons or positrons, and (3) gamma radiation consisting of electromagnetic waves.

The most commonly used unit for radioactivity in water is picocuries per liter $(\mathrm{pCi} / \mathrm{L})$. One Curie is the activity of 1 gram of radium, which is equal to $3.7 \times 10^{10}$ atomic disintegrations per second. Activity refers to the number of particles emitted by a radionuclide. The rate of decay is proportional to the number of atoms present and inversely proportional to half-life. The half-life is the amount of time it takes for a radioactive element to decay to one half its original quantity.

Naturally occurring radioactivity in groundwater is produced primarily by the radioactive decay of uranium- 238 and thorium-232. These isotopes disintegrate in steps emitting either alpha or beta particles and forming a series of radioactive nuclide "daughter" products, mostly short lived, until a stable lead isotope is produced. The uranium-238 decay series produces the greatest amount of radioactivity in natural groundwater (Hem, 1985, p. 147). Uranium-238 has a half-life of $4.5 \times 10^{9}$ years. Its daughter products include radium-226 (half-life of 1,620 years) and radon-222 (half-life of 3.8 days). 
Table 7. Summary statistics for concentrations and activities of radioactive constituents in groundwater samples collected from 34 wells in Wayne County, Pennsylvania, 2011 and 2013.

[Gross alpha and beta radioactivity analyses by TestAmerica Laboratories, Inc., in Richland, Washington; $\mu \mathrm{g} / \mathrm{L}$, micrograms per liter; $\mathrm{pCi} / \mathrm{L}$, picocuries per liter; n, number of samples; R, not detected, result below sample specific critical level, value is critical level; <, less than the laboratory detection limit]

\begin{tabular}{|c|c|c|c|c|c|c|c|c|c|c|c|c|}
\hline \multirow[b]{2}{*}{ Constituent } & \multicolumn{3}{|c|}{ All wells } & \multicolumn{3}{|c|}{$\begin{array}{l}\text { Catskill Formation, } \\
\text { undifferentiated } \\
\qquad(\mathrm{n}=17)\end{array}$} & \multicolumn{3}{|c|}{$\begin{array}{l}\text { Long Run and Walcksville } \\
\text { Members of the Catskill Forma- } \\
\text { tion, undivided } \\
(\mathrm{n}=7)\end{array}$} & \multicolumn{3}{|c|}{$\begin{array}{l}\text { Poplar Gap and Packerton Mem- } \\
\text { bers of the Catskill Formation, } \\
\text { undivided } \\
(n=10)\end{array}$} \\
\hline & $\begin{array}{l}\text { Minimum } \\
\text { activity } \\
\text { or } \\
\text { concen- } \\
\text { tration }\end{array}$ & $\begin{array}{l}\text { Median } \\
\text { activity } \\
\text { or } \\
\text { concen- } \\
\text { tration }\end{array}$ & $\begin{array}{l}\text { Maximum } \\
\text { activity } \\
\text { or } \\
\text { concen- } \\
\text { tration }\end{array}$ & $\begin{array}{l}\text { Minimum } \\
\text { activity } \\
\text { or } \\
\text { concen- } \\
\text { tration }\end{array}$ & $\begin{array}{l}\text { Median } \\
\text { activity } \\
\text { or } \\
\text { concen- } \\
\text { tration }\end{array}$ & $\begin{array}{l}\text { Maxi- } \\
\text { mum } \\
\text { activity } \\
\text { or } \\
\text { concen- } \\
\text { tration }\end{array}$ & $\begin{array}{l}\text { Mini- } \\
\text { mum } \\
\text { activity } \\
\text { or } \\
\text { concen- } \\
\text { tration }\end{array}$ & $\begin{array}{c}\text { Median } \\
\text { activity } \\
\text { or } \\
\text { concen- } \\
\text { tration }\end{array}$ & $\begin{array}{l}\text { Maxi- } \\
\text { mum } \\
\text { activity } \\
\quad \text { or } \\
\text { concen- } \\
\text { tration }\end{array}$ & $\begin{array}{l}\text { Mini- } \\
\text { mum } \\
\text { activity } \\
\text { or } \\
\text { concen- } \\
\text { tration }\end{array}$ & $\begin{array}{l}\text { Median } \\
\text { activity } \\
\text { or } \\
\text { concen- } \\
\text { tration }\end{array}$ & $\begin{array}{l}\text { Maxi- } \\
\text { mum } \\
\text { activity } \\
\quad \text { or } \\
\text { concen- } \\
\text { tration }\end{array}$ \\
\hline $\begin{array}{c}\text { Gross alpha } \\
\text { radioactivity, } \\
\text { 72-hour } \\
\text { count } \\
(\mathrm{pCi} / \mathrm{L})\end{array}$ & R 0.03 & 1.2 & 8.1 & R 0.05 & 0.72 & 6.6 & R 0.05 & 1.8 & 8.1 & R 0.03 & 1.6 & 6.8 \\
\hline $\begin{array}{l}\text { Radon-222, } \\
\text { dissolved } \\
(\mathrm{pCi} / \mathrm{L})\end{array}$ & 110 & 2,105 & 7,180 & 475 & 2,090 & 3,940 & 505 & 2,370 & 7,180 & 110 & 2,035 & 5,160 \\
\hline $\begin{array}{l}\text { Uranium, } \\
\text { dissolved } \\
(\mu \mathrm{g} / \mathrm{L})\end{array}$ & $<0.004$ & 0.437 & 10.6 & 0.010 & 0.350 & 5.66 & 0.012 & 2.3 & 10 & 0.042 & 1.63 & 10.6 \\
\hline
\end{tabular}

Radon-222, a decay product of radium-226, is a colorless, odorless, chemically inert, alpha-particle-emitting gas, which is soluble in water. The end product of the decay series is the stable isotope lead-206.

Activities of radon-222 in water from the 34 sampled wells ranged from 110 to $7,180 \mathrm{pCi} / \mathrm{L}$; the median activity was 2,105 pCi/L (table 7). Median radon-222 activities were similar among geologic units. The USEPA does not regulate radon-222 in drinking water. However, under the framework specified by the 1999 Notice for the Proposed Radon in Drinking Water Rule (Federal Register, 1999), the USEPA proposed an alternative maximum contaminant level (AMCL) of 4,000 pCi/L for radon-222 for community water systems that use groundwater for all or some of the supply in states with an enhanced indoor radon program. For states without an enhanced indoor air program, USEPA proposed an MCL of $300 \mathrm{pCi} / \mathrm{L}$ for radon-222. Water samples from 33 of the 34 wells sampled ( 97 percent) exceeded the proposed USEPA MCL of $300 \mathrm{pCi} / \mathrm{L}$, and 4 water samples (12 percent of sampled wells) exceeded the proposed USEPA AMCL of 4,000 pCi/L for radon-222.
The gross alpha-particle radioactivity (72-hour count) in water from the 34 sampled wells ranged from less than the detection limit to $8.1 \mathrm{pCi} / \mathrm{L}$; the median activity was $1.2 \mathrm{pCi} / \mathrm{L}$ (table 7). Alpha particles are counted at 72 hours and 30 days because some alpha-particle emitters, such as radium-224 (half-life of 3.6 days), would not be present in the 30-day count. Gross alpha-particle activity in the 30-day count was similar to or slightly less than the activity in the 72-hour count (table 12). No water sample exceeded the USEPA MCL of $15 \mathrm{pCi} / \mathrm{L}$ for gross alpha-particle activity (table 2 ).

The gross-beta particle radioactivity (72-hour count) ranged from less than the detection limit to $5.6 \mathrm{pCi} / \mathrm{L}$. Gross beta-particle activity in the 30-day count was similar to or slightly greater than the activity in the 72-hour count in about two-thirds of the samples (table 12).

The concentration of uranium ranged from less than 0.004 to $10.6 \mu \mathrm{g} / \mathrm{L}$. The median concentration was $0.437 \mu \mathrm{g} / \mathrm{L}$. No water samples exceeded the USEPA MCL of $30 \mu \mathrm{g} / \mathrm{L}$ for uranium. 


\section{Summary and Conclusions}

Wayne County, Pennsylvania, is underlain by the Marcellus Shale, which is being developed elsewhere in Pennsylvania for natural gas. All residents of Wayne County rely on groundwater as a source of water supply. Drilling and hydraulic fracturing of horizontal natural gas wells have the potential to contaminate freshwater aquifers that provide drinking water and the base flow of streams. This study, conducted by the U.S. Geological Survey (USGS) in cooperation with the Pennsylvania Department of Conservation and Natural Resources, Bureau of Topographic and Geologic Survey (Pennsylvania Geological Survey), provides a groundwater-quality baseline for Wayne County prior to development of the natural-gas resource in the Marcellus Shale.

Wayne County occupies 750.5 square miles in northeastern Pennsylvania and is rural with a 2013 estimated population of 51,548. Seasonal dwellings made up 35.5 percent of housing units in the county in 2010. The county is underlain by bedrock (mostly shales and sandstones) of Pennsylvanian and Devonian age. Wells completed in the Devonian-age Catskill Formation (undifferentiated); the Poplar Gap and Packerton Members of the Catskill Formation, undivided; and the Long Run and Walcksville Members of the Catskill Formation, undivided, were sampled for this study.

Water samples were collected once from 34 domestic wells ranging in depth from 75 to 1,300 ft during August 2011 (2 wells) and August and September 2013 (32 wells) and analyzed to characterize their physical and chemical quality. Samples were analyzed for 45 constituents and properties, including nutrients, major ions, metals and trace elements, radioactivity, and dissolved gases, including methane, ethane, and radon-222. The quality of the sampled groundwater was considered to be very good, generally within U.S. Environmental Protection Agency (USEPA) drinking-water standards, although in some samples, the concentrations of a few constituents exceeded USEPA drinking-water standards and health advisories.

Physical properties measured in the field include temperature, $\mathrm{pH}$, and specific conductance; other properties measured include alkalinity and dissolved oxygen concentration. The $\mathrm{pH}$ of water samples ranged from 5.5 to 9.3; the median $\mathrm{pH}$ was 7.0. The $\mathrm{pH}$ of 14 of the 34 samples (41 percent) was outside the USEPA secondary maximum contaminant level (SMCL) range of 6.5 to 8.5. Eleven samples had a pH less than 6.5, and three samples had a $\mathrm{pH}$ greater than 8.5 . Alkalinity ranged from 15.4 to 188 milligrams per liter $(\mathrm{mg} / \mathrm{L})$ as calcium carbonate $\left(\mathrm{CaCO}_{3}\right)$; the median concentration was $83.4 \mathrm{mg} / \mathrm{L}$ as $\mathrm{CaCO}_{3}$. In general, water samples with a higher $\mathrm{pH}$ have a higher alkalinity. Specific conductance ranged from 50 to 614 microsiemens per centimeter at 25 degrees Celsius $(\mu \mathrm{S} /$ $\mathrm{cm}$ ); the median specific conductance was $219 \mu \mathrm{S} / \mathrm{cm}$. The mean ratio of total dissolved solids to specific conductance was 0.61 for the 34 water samples.

Dissolved oxygen concentrations ranged from 0.2 to $11.5 \mathrm{mg} / \mathrm{L}$ with a median of $4.7 \mathrm{mg} / \mathrm{L}$. The dissolved oxygen concentration was less than $1 \mathrm{mg} / \mathrm{L}$ in water samples from six wells. Low dissolved oxygen concentrations were associated with higher $\mathrm{pH}$ values; 5 of the 6 water samples with a dissolved oxygen concentration less than $1 \mathrm{mg} / \mathrm{L}$ had a pH greater than 7.8. Median dissolved oxygen concentrations ranged from $4.8 \mathrm{mg} / \mathrm{L}$ for the Poplar Gap and Packerton Members to $5.9 \mathrm{mg} / \mathrm{L}$ for the Catskill Formation, undifferentiated.

Concentrations of dissolved methane ranged from less than 0.00006 to $3.3 \mathrm{mg} / \mathrm{L}$ with a median concentration of $0.00019 \mathrm{mg} / \mathrm{L}$. None of the dissolved methane concentrations exceeded the Pennsylvania action level of $7 \mathrm{mg} / \mathrm{L}$. Methane was detected in 22 of the 34 wells sampled ( 65 percent). Methane concentrations were greatest in water samples with $\mathrm{pH}$ of 7.8 or greater, ranging from 0.04 to $3.3 \mathrm{mg} / \mathrm{L}$ in 5 of the 22 water samples in which it was detected. These 5 samples also had among the lowest concentrations of dissolved oxygen (less than or equal to $0.5 \mathrm{mg} / \mathrm{L}$ ).

Water samples were analyzed for the hydrocarbon gases ethane, ethylene, propane, propylene, iso-butane, and N-butane and for the hydrocarbon liquids iso-pentane, $\mathrm{N}$-pentane, and hexane. Ethane was detected only in the four water samples with methane concentrations greater than $0.08 \mathrm{mg} / \mathrm{L}$. The other hydrocarbons were not detected. Three water samples, which had sufficient dissolved methane concentrations (greater than $0.9 \mathrm{mg} / \mathrm{L}$ ) for isotopic analysis, were analyzed for isotopes of carbon and hydrogen in the methane. The $\delta^{13} \mathrm{C}$ values ranged from -60.32 to -53.96 per mil, and the $\delta \mathrm{D}$ values ranged from -193.8 to -180.0 per mil. Values for two wells fell within the range for a thermogenic natural gas source. The values for one well fell in the area between a thermogenic and a microbial (biogenic) gas source, indicating that it probably is a mixture from both sources

The total dissolved solids concentration ranged from 33 to $346 \mathrm{mg} / \mathrm{L}$ with a median of $126 \mathrm{mg} / \mathrm{L}$. Median total dissolved solids concentrations ranged from $102 \mathrm{mg} / \mathrm{L}$ in the Catskill Formation, undifferentiated, to $136 \mathrm{mg} / \mathrm{L}$ in the Poplar Gap and Packerton Members. Sodium concentrations ranged from 1.07 to $116 \mathrm{mg} / \mathrm{L}$ with a median of $9.42 \mathrm{mg} / \mathrm{L}$. Median sodium concentrations ranged from $8.43 \mathrm{mg} / \mathrm{L}$ in the Catskill Formation, undifferentiated, to $11.4 \mathrm{mg} / \mathrm{L}$ in the Poplar Gap and Packerton Members. The sodium concentration exceeded the USEPA health advisory for sodium of $20 \mathrm{mg} / \mathrm{L}$ in 7 of the 34 water samples (21 percent). Chloride concentrations ranged from 0.55 to $90 \mathrm{mg} / \mathrm{L}$ with a median of $4.95 \mathrm{mg} / \mathrm{L}$. Median chloride concentrations ranged from $1.92 \mathrm{mg} / \mathrm{L}$ in the Long Run and Walcksville Members to $8.76 \mathrm{mg} / \mathrm{L}$ in the Poplar Gap and Packerton Members.

Concentrations of nutrients in samples from the 34 wells were low. Nitrite, ammonia, and orthophosphate, when detected, were present in concentrations less than $0.1 \mathrm{mg} / \mathrm{L}$ as nitrogen $(\mathrm{N})$ and phosphorus $(\mathrm{P})$, respectively. Median concentrations of ammonia (less than $0.01 \mathrm{mg} / \mathrm{L}$ as $\mathrm{N}$ ) and nitrite (less than $0.001 \mathrm{mg} / \mathrm{L}$ as $\mathrm{N}$ ) were less than the laboratory detection limit. The median concentration of orthophosphate was $0.016 \mathrm{mg} / \mathrm{L}$ as $P$. Nitrate is the most prevalent nitrogen species in groundwater. Because concentrations of nitrite are 
so low, nitrate plus nitrite concentrations represent nitrate concentrations. The concentration of nitrate as $\mathrm{N}$ ranged from less than 0.04 to $2.75 \mathrm{mg} / \mathrm{L}$ as $\mathrm{N}$ with a median of $0.632 \mathrm{mg} / \mathrm{L}$ as $\mathrm{N}$. All nitrate concentrations were less than the USEPA maximum contaminant level (MCL) of $10 \mathrm{mg} / \mathrm{L}$ for nitrate as $\mathrm{N}$.

Metals and other trace elements typically are present in low concentrations in natural waters. Two water samples exceeded the USEPA MCL for arsenic, and one sample exceeded the USEPA SMCL for manganese. Concentrations of dissolved arsenic in water from the 34 wells ranged from 0.06 to 21.8 micrograms per liter $(\mu \mathrm{g} / \mathrm{L})$ with a median of $0.59 \mu \mathrm{g} / \mathrm{L}$. Median arsenic concentrations ranged from $0.49 \mu \mathrm{g} / \mathrm{L}$ in the Catskill Formation, undifferentiated, to $1 \mu \mathrm{g} / \mathrm{L}$ in the Long Run and Walcksville Members. Water samples from 2 of the 34 sampled wells ( 6 percent) exceeded the USEPA MCL of $10 \mu \mathrm{g} / \mathrm{L}$ for arsenic; one well is in the Catskill Formation, undifferentiated, and one well is in the Poplar Gap and Packerton Members. The concentration of arsenic $(9.92 \mu \mathrm{g} / \mathrm{L})$ in water from one well in the Catskill Formation, undifferentiated, was just less than the USEPA MCL. Concentrations of dissolved manganese in water from the 34 wells ranged from less than 0.15 to $61.5 \mu \mathrm{g} / \mathrm{L}$ with a median of $0.42 \mu \mathrm{g} / \mathrm{L}$. Median manganese concentrations ranged from $0.21 \mu \mathrm{g} / \mathrm{L}$ for the Poplar Gap and Packerton Members to $1.86 \mu \mathrm{g} / \mathrm{L}$ for the Long Run and Walcksville Members. Water samples from 1 of the 34 wells ( 3 percent) exceeded the USEPA SMCL of $50 \mu \mathrm{g} / \mathrm{L}$ for manganese; the well is in the Long Run and Walcksville Members. The concentration was less than the USEPA lifetime health advisory of $300 \mu \mathrm{g} / \mathrm{L}$ for manganese.

Analyses were conducted for radioactivity and radionuclides - gross alpha radioactivity, gross beta radioactivity, uranium, and dissolved radon-222. Activities of radon-222 in water from the 34 sampled wells ranged from 110 to 7,180 picocuries per liter $(\mathrm{pCi} / \mathrm{L})$; the median activity was 2,105 pCi/L. Median radon-222 activities were similar among geologic units. Water samples from 33 of the 34 wells sampled (97 percent) exceeded the proposed USEPA MCL of $300 \mathrm{pCi} / \mathrm{L}$, and 4 water samples (12 percent of sampled wells) exceeded the proposed USEPA alternate MCL of $4,000 \mathrm{pCi} / \mathrm{L}$ for radon-222. The gross alpha-particle radioactivity (72-hour count) in water from the 34 sampled wells ranged from less than the detection limit to $8.1 \mathrm{pCi} / \mathrm{L}$; the median activity was $1.2 \mathrm{pCi} / \mathrm{L}$. No water sample exceeded the USEPA MCL of $15 \mathrm{pCi} / \mathrm{L}$ for gross alpha-particle activity. The grossbeta particle radioactivity (72-hour count) ranged from less than the detection limit to $5.6 \mathrm{pCi} / \mathrm{L}$. The concentration of uranium ranged from 0.004 to $10.6 \mu \mathrm{g} / \mathrm{L}$ with a median of $0.437 \mu \mathrm{g} / \mathrm{L}$. No water samples exceeded the USEPA MCL of $30 \mu \mathrm{g} / \mathrm{L}$ for uranium.

Differences in groundwater chemistry were related to $\mathrm{pH}$. High $\mathrm{pH}$ waters (greater than or equal to 7.6) generally had low dissolved oxygen concentrations, indicating reducing conditions in the aquifer. High $\mathrm{pH}$ waters had relatively elevated concentrations of methane, arsenic, boron, bromide, fluoride, lithium, and sodium. Water samples with a $\mathrm{pH}$ greater than 7.8 had methane concentrations equal to or greater than $0.04 \mathrm{mg} / \mathrm{L}$. In addition, high $\mathrm{pH}$ waters also had low concentrations of copper, nickel, and zinc.

\section{References Cited}

Berg, T.M., Sevon, W.D., and Bucek, M.F., 1977, Geology and mineral resources of the Pocono Pines and Mount Pocono quadrangles, Monroe County, Pennsylvania: Pennsylvania Geological Survey, 4th series, Atlas 204cd, 66 p., 2 pls., scale 1:24,000.

Coleman, D.D., Liu, C.L., Hackley, K.C., and Benson, L.J., 1993, Identification of landfill methane using carbon and hydrogen isotope analysis: Proceedings of Sixteenth International Madison Waste Conference, University of Wisconsin, September 22-23, 1993, p. 303-314.

Commonwealth of Pennsylvania, 2014, the Pennsylvania code chapter 78. Oil and gas wells, accessed on March 31, 2014, at $h t t p: / / w w w . p a c o d e . c o m / s e c u r e / d a t a / 025 /$ chapter78/ chap78toc.html.

Delaware River Basin Commission, 2014, Natural gas drilling

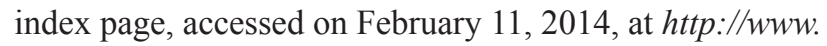
state.nj.us/drbc/programs/natural/.

Dzombak, D.A., and Morel, F.M.M., 1990, Surface complexation modeling: hydrous ferric oxide: New York, WileyInterscience, $393 \mathrm{p}$.

Eckhardt, D.A., and Sloto, R.A., 2012, Baseline groundwater quality in national park units within the Marcellus and Utica shale gas plays, New York, Pennsylvania, and West Virginia, 2011: U.S. Geological Survey Open-File Report 2012-1150, 20 p. at http://pubs.er.usgs.gov/publication/ ofr 20121150 .

Federal Register, 1999, National primary drinking water regulations; radon-222: Federal Register, v. 64, no. 211, p. 59245-59294.

Hem, J.D., 1985, Study and interpretation of the chemical characteristics of natural water (3d ed.): U.S. Geological Survey Water-Supply Paper 2254, 264 p.

Kargbo, D.M., Wilhelm, R.G., and Campbell, D.J., 2010, Natural gas plays in the Marcellus shale-Challenges and potential opportunities: Environmental Science and Technology, v. 44, p. 5679-5684.

Kerr, R.A., 2010, Natural gas from shale bursts onto the scene: Science, v. 328, p. 1624-1626. 
Miles, C.E., and Whitfield, T.G., comps., 2001, Bedrock geology of Pennsylvania: Pennsylvania Geological Survey, 4th series, digital dataset, scale 1:250,000.

Pennsylvania Department of Environmental Protection, 2014a, Wells drilled by county, accessed January 28, 2014, at http://www.depreportingservices.state.pa.us/ ReportServer/Pages/ReportViewer.aspx?/Oil_Gas/ Wells_Drilled_By_County.

Pennsylvania Department of Environmental Protection, $2014 \mathrm{~b}$, Year to date permits issued by well type, accessed January 28, 2014, at http://www.depreportingservices.state. pa.us/ReportServer/Pages/ReportViewer.aspx?/Oil_Gas/ Permits_Issued_Count_by_Well_Type_YTD.

Pennsylvania Geological Survey, 2014, Pennsylvania groundwater information system (PAGWIS) documentation, accessed February 11, 2014, at http://www.dcnr.state.pa.us/ topogeo/groundwater/pagwis/index.htm.

Schoell, M., 1980, The hydrogen and carbon isotopic composition of methane from natural gases of various origins: Geochimica et Cosmochimica Acta, v. 44, p. 649-661.

Sevon, W.D., 1975, Geology and mineral resources of the Tobyhanna and Buck Hill Falls quadrangles, Monroe County, Pennsylvania: Pennsylvania Geological Survey, 4th series, Atlas 204ab, 2 pls.

Sevon, W.D., 2000, Physiographic provinces of Pennsylvania: Pennsylvania Geological Survey, 4th series, Map 13, 1 sheet.

Stumm, Werner, and Morgan, J.J., 1996, Aquatic chemistry (3d ed.): New York, John Wiley and Sons, 1022 p.

Taylor, L.E., 1984, Groundwater resources of the upper Susquehanna River Basin, Pennsylvania: Pennsylvania Geological Survey, 4th series, Water Resource Report 58, $136 \mathrm{p}$.

Taylor, S.W., Lollar, B.S., and Wassenaar, L.I., 2000, Bacteriogenic ethane in near-surface aquifers: implications for leaking hydrocarbon well bores: Environmemtal Science and Technology, v. 34, p. 4727-4732.

U.S. Census Bureau, 2014, Annual estimates of the resident population: April 1, 2010 to July 1, 2013, accessed March 31, 2014, at http://factfinder2.census.gov/faces/ tableservices/jsf/pages/productview.xhtml? src $=b k m k$.

U.S. Environmental Protection Agency, 2003, Drinking water advisory: consumer acceptability advice and health effects analysis on sodium: U.S. Environmental Protection Agency EPA 822-R-03-006, 29 p.
U.S. Environmental Protection Agency, 2004, Drinking water health advisory for manganese: U.S. Environmental Protection Agency EPA 822-R-04-003, 49 p.

U.S. Environmental Protection Agency, 2012, 2012 Edition of the drinking water standards and health advisories: U.S. Environmental Protection Agency EPA 822-S-12-001, accessed February 10, 2014, at http://water.epa.gov/action/ advisories/drinking/upload/dwstandards2012.pdf.

U.S. Environmental Protection Agency, 2014, Natural gas extraction-hydraulic fracturing, accessed February 12, 2014, at http://water.epa.gov/type/groundwater/uic/class2/ hydraulicfracturing/.

U.S. Geological Survey, 2014a, National Water Quality Laboratory, accessed February 11, 2014, at http://nwql.usgs. gov/.

U.S. Geological Survey, 2014b, USGS water data for Pennsylvania, accessed February 11, 2014, at http:// waterdata.usgs.gov/pa/nwis/nwis.

U.S. Geological Survey, variously dated, National field manual for the collection of water-quality data: U.S. Geological Survey Techniques of Water-Resources Investigations, book 9, chap. A1-A9, accessed December 5, 2012, at http://pubs. water.usgs.gov/twri9A/.

Wayne County Planning Commission, 2010, Wayne County comprehensive plan update, accessed October 28, 2013, at http://planning.co.wayne.pa.us/resource-materials/ wayne-county-comprehensive-plan-update/.

White, I.C., 1881, The geology of Susquehanna County and Wayne County: Pennsylvania Geological Survey, 2nd series, Report G5, 243 p. 
Table 8. Physical properties and dissolved oxygen and methane concentrations for groundwater samples collected from 34 wells in Wayne County, Pennsylvania, 2011 and 2013.

[Well locations are shown in figure 2; site information is listed in table 1; dissolved gas samples were analyzed by Isotech Laboratories, Inc., Champaign, Illinois; $\mathrm{mg} / \mathrm{L}$, milligrams per liter; <, less than the laboratory detection limit; $\mu \mathrm{S} / \mathrm{cm}$, microsiemens per centimeter at 25 degrees Celsius; --, no data; nd, not detected; $\mathrm{CaCO}_{3}$, calcium carbonate; REP, replicate sample; BLANK, field blank sample; values in red exceed drinking-water standard (U.S. Environmetal Protection Agency, 2012]

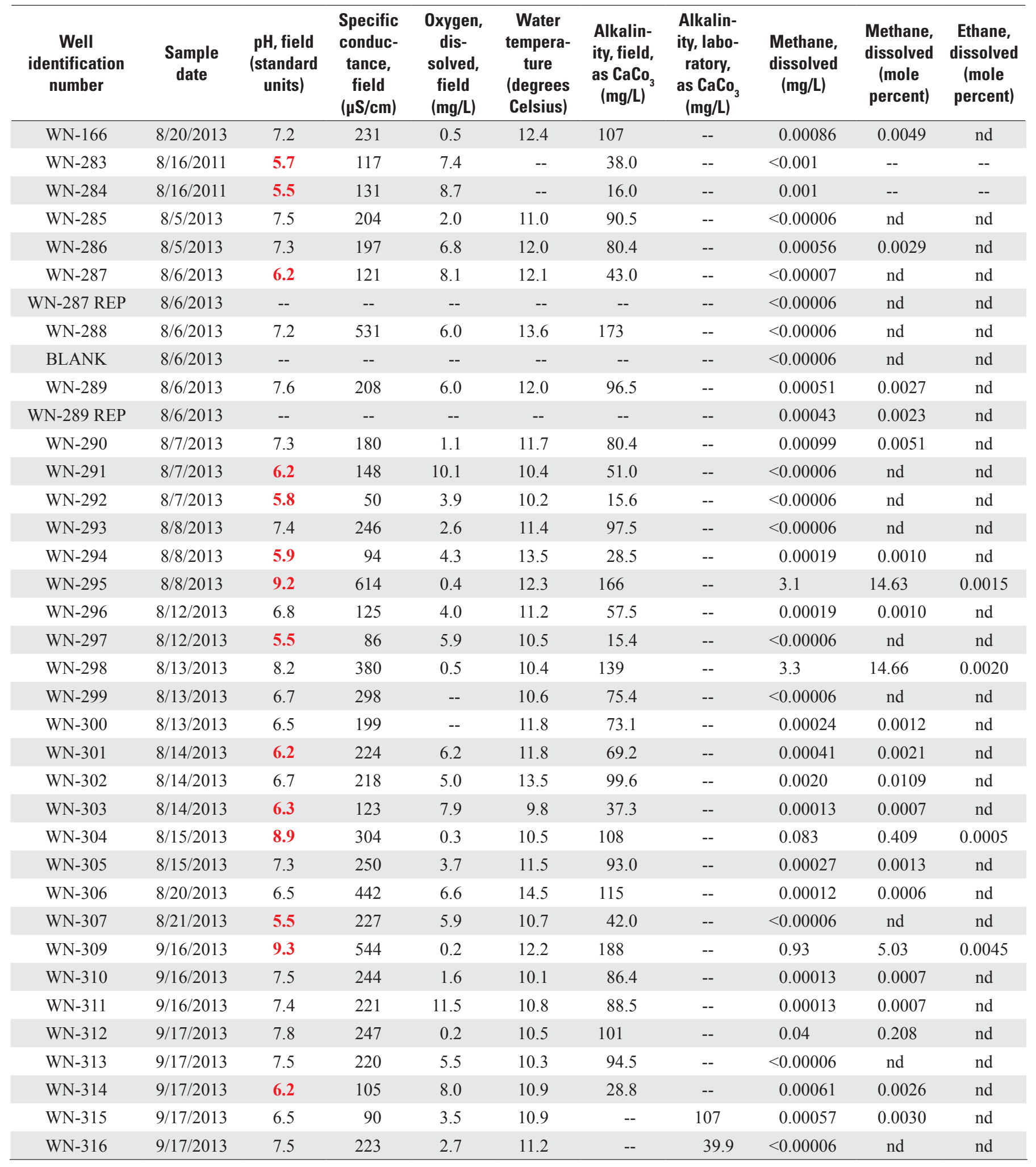


Table 9. Concentrations of major ions in groundwater samples collected from 34 wells in Wayne County, Pennsylvania, 2011 and 2013.

[Well locations are shown in figure 2; site information is listed in table1; $\mathrm{mg} / \mathrm{L}$, milligrams per liter; ${ }^{\circ} \mathrm{C}$, degrees Celsius; $<$, less than the laboratory detection limit; E, estimated value; REP, replicate sample; BLANK, field blank sample]

\begin{tabular}{|c|c|c|c|c|c|c|c|c|c|c|c|}
\hline $\begin{array}{c}\text { Well } \\
\text { identification } \\
\text { number }\end{array}$ & $\begin{array}{c}\text { Sample } \\
\text { date }\end{array}$ & $\begin{array}{l}\text { Calcium, } \\
\text { dis- } \\
\text { solved } \\
\text { (mg/L) }\end{array}$ & $\begin{array}{c}\text { Magne- } \\
\text { sium, } \\
\text { dis- } \\
\text { solved } \\
\text { (mg/L) }\end{array}$ & $\begin{array}{c}\text { Sodium, } \\
\text { dis- } \\
\text { solved } \\
\text { (mg/L) }\end{array}$ & $\begin{array}{l}\text { Potas- } \\
\text { sium, } \\
\text { dis- } \\
\text { solved } \\
\text { (mg/L) }\end{array}$ & $\begin{array}{c}\text { Bromide, } \\
\text { dissolved } \\
\text { (mg/L) }\end{array}$ & $\begin{array}{l}\text { Chloride, } \\
\text { dis- } \\
\text { solved } \\
\text { (mg/L) }\end{array}$ & $\begin{array}{c}\text { Fluoride, } \\
\text { dis- } \\
\text { solved } \\
\text { (mg/L) }\end{array}$ & $\begin{array}{l}\text { Silica, } \\
\text { dis- } \\
\text { solved } \\
\text { (mg/L) }\end{array}$ & $\begin{array}{c}\text { Sulfate, } \\
\text { dis- } \\
\text { solved } \\
\text { (mg/L) }\end{array}$ & $\begin{array}{c}\text { Total } \\
\text { dis- } \\
\text { solved } \\
\text { solids } \\
\text { dried at } \\
180^{\circ} \mathrm{C} \\
(\mathrm{mg} / \mathrm{L})\end{array}$ \\
\hline WN-166 & $8 / 20 / 2013$ & 33.1 & 4.41 & 8.54 & 0.88 & 0.012 & 1.18 & 0.10 & 8.12 & 7.32 & 136 \\
\hline WN-283 & $8 / 16 / 2011$ & 13.0 & 2.99 & 3.51 & 0.96 & $<0.01$ & 5.58 & $<0.04$ & 9.68 & 9.55 & 82 \\
\hline WN-284 & $8 / 16 / 2011$ & 8.99 & 2.92 & 9.35 & 0.87 & $<0.01$ & 19.0 & $<0.04$ & 8.82 & 10.0 & 75 \\
\hline WN-285 & $8 / 5 / 2013$ & 27.2 & 2.19 & 10.8 & 1.08 & 0.024 & 3.25 & 0.10 & 6.69 & 7.44 & 117 \\
\hline WN-286 & $8 / 5 / 2013$ & 21.7 & 2.96 & 12.7 & 1.07 & 0.022 & 1.81 & 0.09 & 6.47 & 10.3 & 112 \\
\hline WN-287 & $8 / 6 / 2013$ & 16.9 & 1.34 & 3.85 & 0.73 & 0.012 & 1.04 & 0.06 & 5.33 & 6.70 & 73 \\
\hline WN-287 REP & $8 / 6 / 2013$ & 16.9 & 1.35 & 3.86 & 0.71 & $<0.01$ & 1.04 & 0.06 & 5.26 & 6.69 & 73 \\
\hline WN-288 & $8 / 6 / 2013$ & 85.4 & 12.1 & 13.5 & 1.47 & 0.066 & 60.7 & 0.07 & 10.0 & 23.2 & 279 \\
\hline BLANK & $8 / 6 / 2013$ & $<0.022$ & $<0.011$ & $<0.06$ & $<0.03$ & $<0.01$ & $<0.06$ & $<0.01$ & 0.066 & $<0.09$ & $<20$ \\
\hline WN-289 & $8 / 6 / 2013$ & 25.1 & 2.79 & 13.5 & 1.09 & 0.019 & 1.04 & 0.12 & 9.18 & 7.06 & 126 \\
\hline WN-289 REP & $8 / 6 / 2013$ & 24.2 & 2.70 & 13.1 & 1.15 & 0.019 & 1.04 & 0.12 & 9.17 & 7.09 & 125 \\
\hline WN-290 & $8 / 7 / 2013$ & 18.9 & 6.13 & 8.43 & 1.08 & 0.017 & 0.977 & 0.09 & 8.07 & 9.78 & 102 \\
\hline WN-291 & $8 / 7 / 2013$ & 23.0 & 2.15 & 2.79 & 0.56 & 0.019 & 3.68 & 0.04 & 7.29 & 10.9 & 95 \\
\hline WN-292 & $8 / 7 / 2013$ & 5.81 & 1.11 & 1.07 & 0.61 & 0.014 & 0.548 & 0.03 & 4.46 & 4.15 & 33 \\
\hline WN-293 & $8 / 8 / 2013$ & 33.9 & 4.58 & 9.49 & 0.87 & 0.019 & 8.97 & 0.10 & 11.2 & 8.03 & 138 \\
\hline WN-294 & $8 / 8 / 2013$ & 9.70 & 2.59 & 3.42 & 0.83 & 0.020 & 1.92 & 0.06 & 9.9 & 8.38 & 66 \\
\hline WN-295 & $8 / 8 / 2013$ & 2.32 & 0.159 & 116 & 1.42 & 0.77 & 90.0 & 0.39 & 7.9 & 3.08 & 346 \\
\hline WN-296 & $8 / 12 / 2013$ & 15.5 & 3.11 & 4.83 & 0.66 & $<0.01$ & 0.574 & 0.10 & 8.79 & 2.86 & 83 \\
\hline WN-297 & $8 / 12 / 2013$ & 10.9 & 1.36 & 2.17 & 0.42 & 0.030 & 8.55 & 0.03 & 5.74 & 4.09 & 49 \\
\hline WN-298 & $8 / 13 / 2013$ & 9.89 & 2.80 & 66.9 & 1.85 & 0.319 & 34.7 & 0.28 & 7.27 & 1.28 & 221 \\
\hline WN-299 & $8 / 13 / 2013$ & 45.7 & 3.89 & 6.06 & 0.81 & 0.028 & 25.7 & 0.05 & 8.81 & 16.6 & 191 \\
\hline WN-300 & $8 / 13 / 2013$ & $<0.022$ & $<0.011$ & 39.6 & $<0.03$ & 0.026 & 2.7 & 0.11 & 7.53 & 4.29 & 106 \\
\hline WN-301 & $8 / 14 / 2013$ & 28.4 & 3.26 & 10.9 & 1.20 & 0.024 & 12.4 & 0.06 & 8.81 & 11.4 & 125 \\
\hline WN-302 & $8 / 14 / 2013$ & 29.8 & 2.72 & 11.4 & 1.71 & 0.025 & 2.00 & 0.07 & 9.67 & 7.45 & 123 \\
\hline WN-303 & $8 / 14 / 2013$ & 18.3 & 1.66 & 2.44 & 0.51 & 0.024 & 4.91 & 0.03 & 5.33 & 6.31 & 77 \\
\hline WN-304 & $8 / 15 / 2013$ & 4.28 & 0.309 & 59.9 & 0.85 & 0.042 & 8.03 & 0.27 & 8.97 & 20.7 & 202 \\
\hline WN-305 & $8 / 15 / 2013$ & 30.5 & 3.51 & 13.4 & 1.34 & 0.018 & 11.8 & 0.13 & 10.4 & 9.21 & 164 \\
\hline WN-306 & $8 / 20 / 2013$ & 54.8 & 4.88 & 23.4 & 1.52 & 0.047 & 55.8 & 0.07 & 8.29 & 11.8 & 238 \\
\hline WN-307 & $8 / 21 / 2013$ & 21.9 & 2.58 & 14.4 & 1.19 & 0.017 & 30.0 & 0.05 & 5.61 & 8.08 & 131 \\
\hline WN-309 & $9 / 16 / 2013$ & 1.50 & 0.182 & 112 & 1.44 & 0.072 & 21.8 & 1.16 & 9.32 & 20.9 & 326 \\
\hline WN-310 & $9 / 16 / 2013$ & 38.5 & 3.33 & 5.36 & 0.81 & E 0.021 & 4.94 & 0.08 & 8.38 & 7.37 & 134 \\
\hline WN-311 & $9 / 16 / 2013$ & 33.8 & 3.54 & 5.78 & 0.86 & E 0.025 & 4.96 & 0.08 & 9.39 & 10.1 & 133 \\
\hline WN-312 & $9 / 17 / 2013$ & 25.7 & 2.54 & 21.8 & 1.42 & 0.091 & 10.6 & 0.10 & 10.2 & 6.62 & 147 \\
\hline WN-313 & $9 / 17 / 2013$ & 33.4 & 3.25 & 7.24 & 1.00 & E 0.025 & 3.09 & 0.08 & 9.84 & 6.60 & 127 \\
\hline WN-314 & $9 / 17 / 2013$ & 12.0 & 2.81 & 2.90 & 0.45 & 0.045 & 5.53 & 0.04 & 7.32 & 6.35 & 62 \\
\hline WN-315 & $9 / 17 / 2013$ & 33.1 & 3.48 & 10.2 & 1.11 & E 0.017 & 1.43 & 0.10 & 10.3 & 9.41 & 137 \\
\hline WN-316 & $9 / 17 / 2013$ & 11.3 & 2.48 & 3.02 & 0.60 & E 0.013 & 0.635 & 0.09 & 14.0 & 6.74 & 61 \\
\hline
\end{tabular}


Table 10. Concentrations of nutrients in groundwater samples collected from 34 wells in Wayne County, Pennsylvania, 2011 and 2013.

[Well locations are shown in figure 2; site information is listed in table 1; $\mathrm{mg} / \mathrm{L}$, milligrams per liter; $\mathrm{N}$, nitrogen; $\mathrm{P}$, phosphorus; <, less than the laboratory detection limit; REP, replicate sample; BLANK, field blank sample]

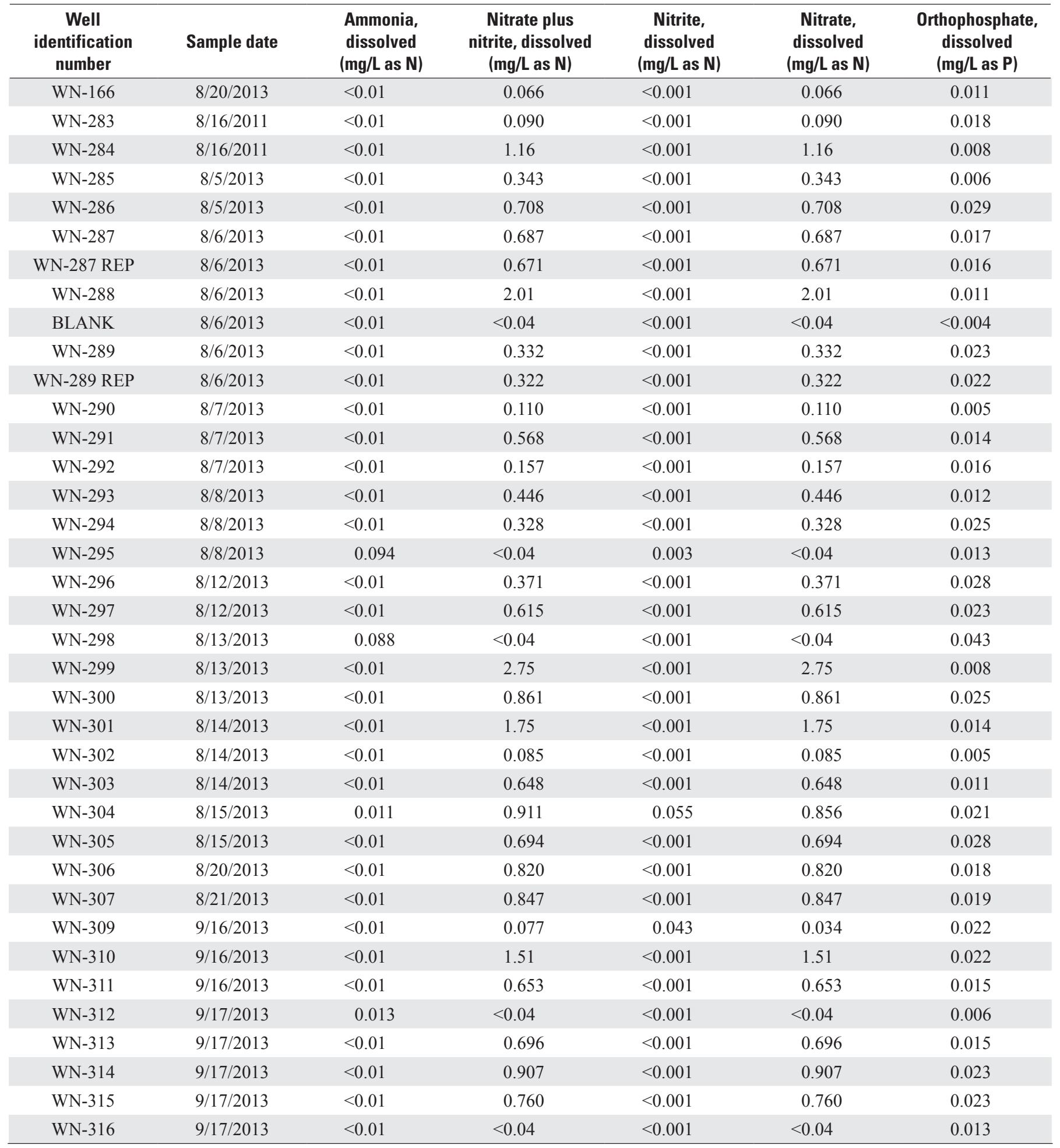




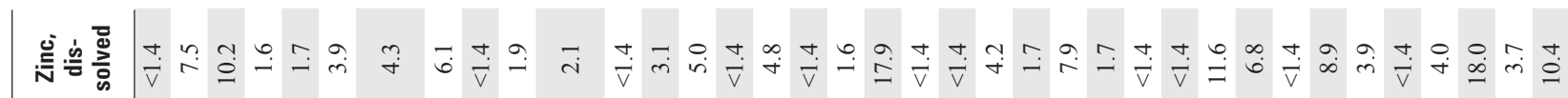

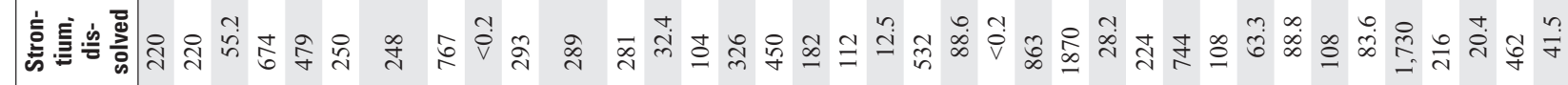

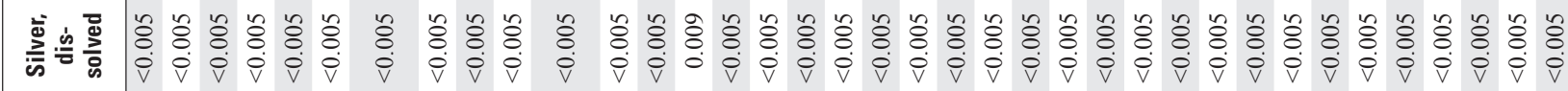

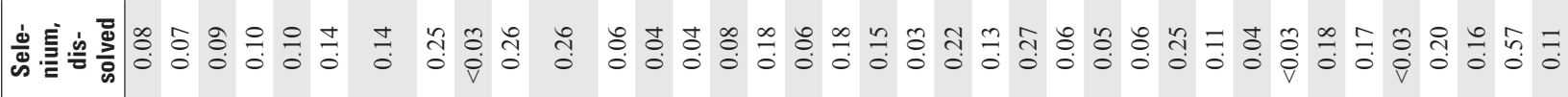

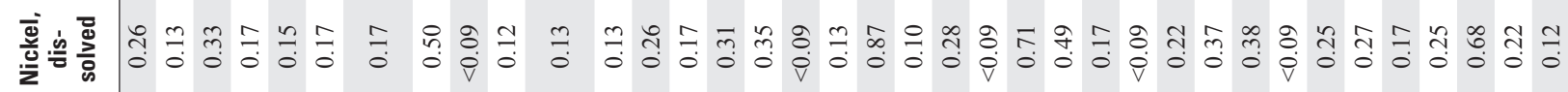

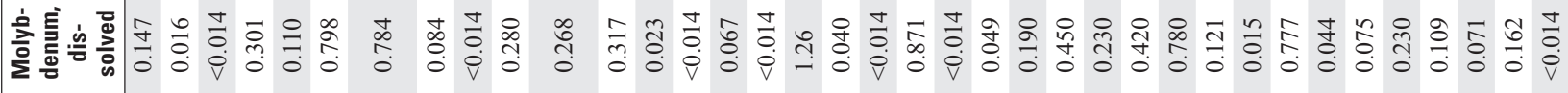

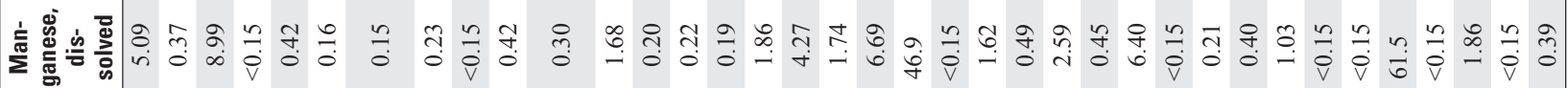

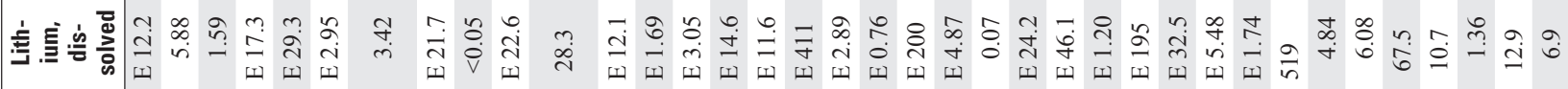

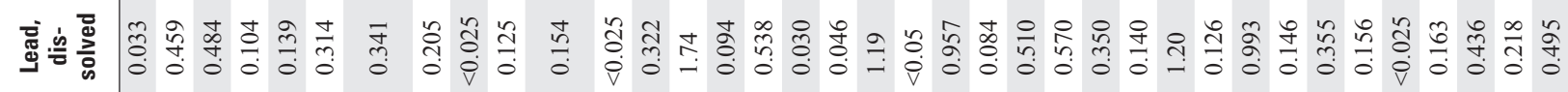

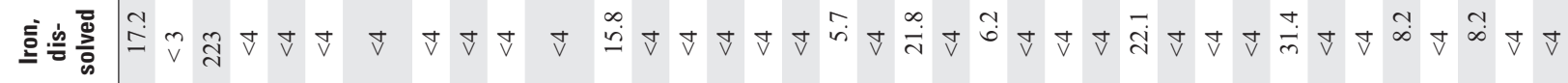

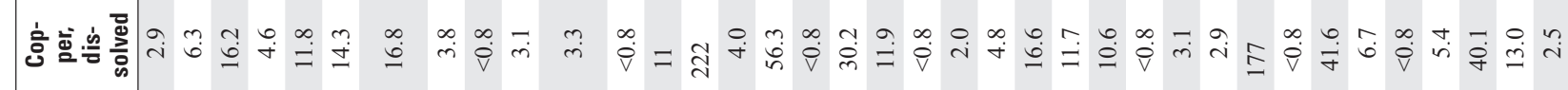

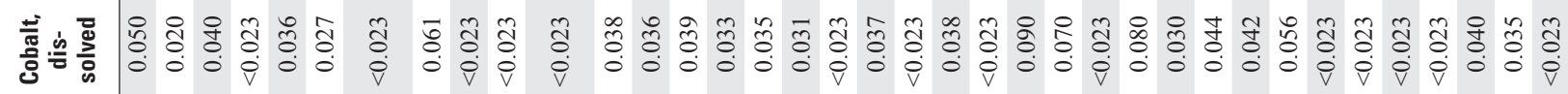

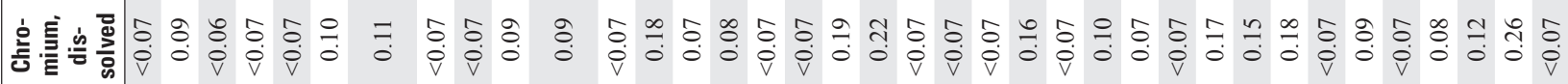

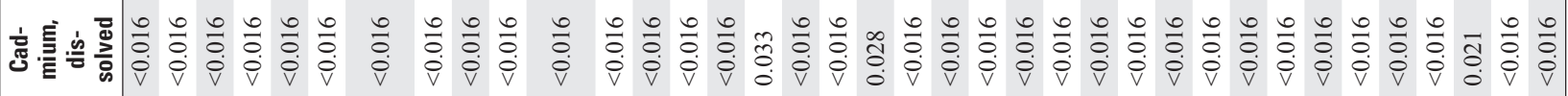

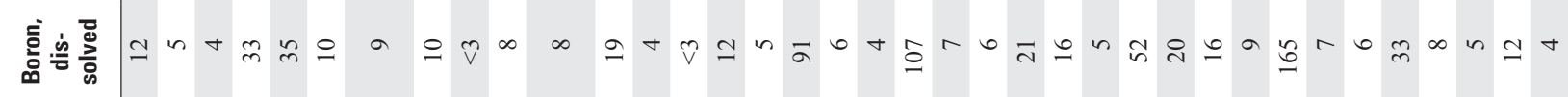

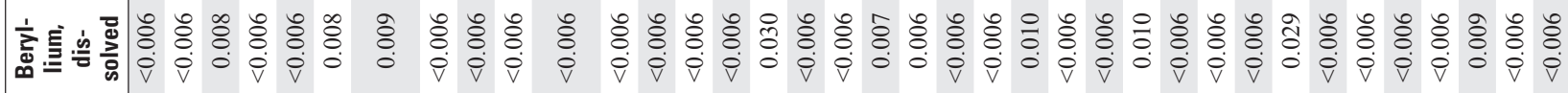

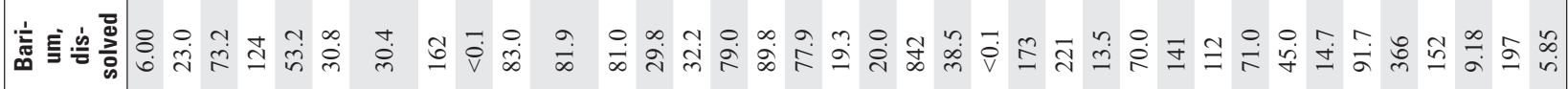

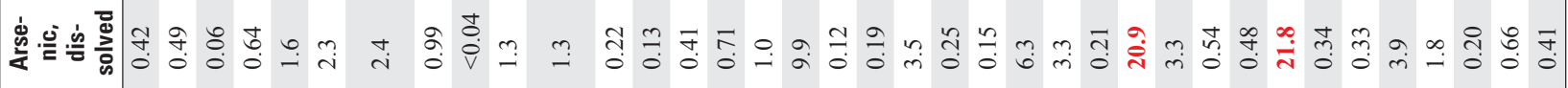

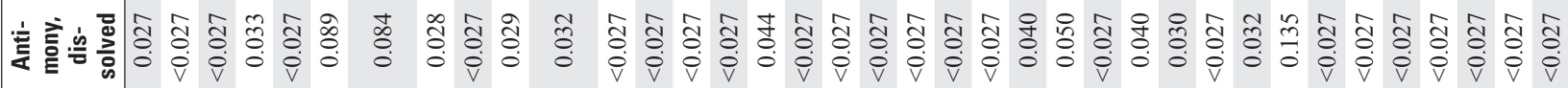

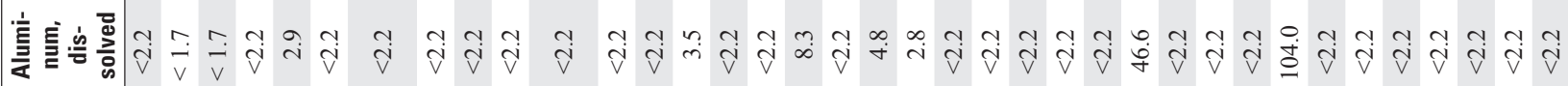
$\exists \bar{\Phi}$

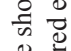
产

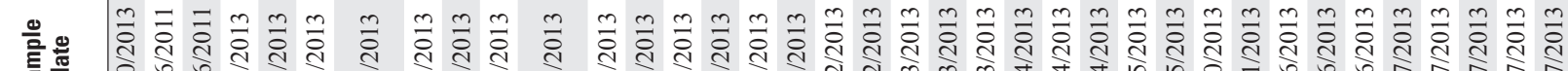
竞总

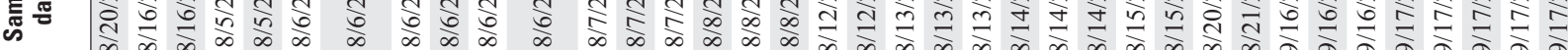

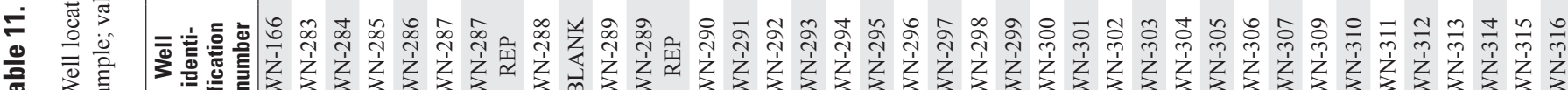




\begin{tabular}{|c|c|c|c|c|c|c|c|c|}
\hline & & & గnc & $\stackrel{\infty}{\circ}$ & & 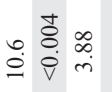 & & 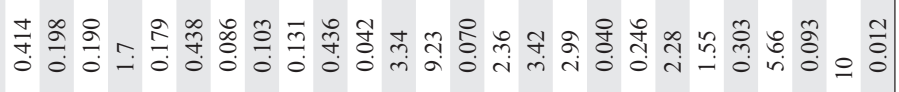 \\
\hline 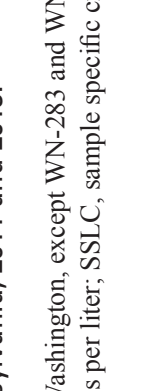 & 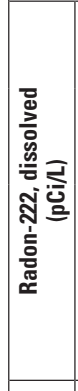 & 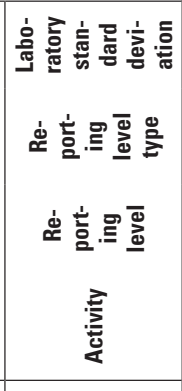 & 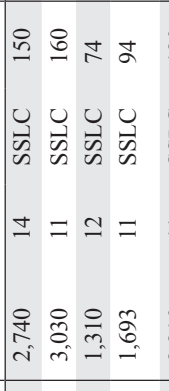 & Iิ & 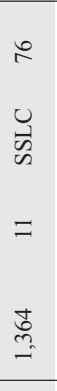 & 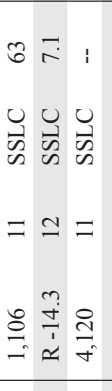 & $\begin{array}{l}= \\
\text { \& } \\
\stackrel{+}{+}\end{array}$ & 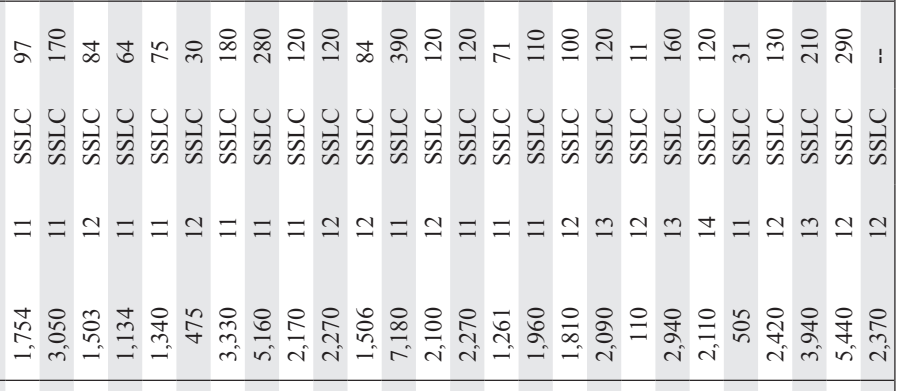 \\
\hline 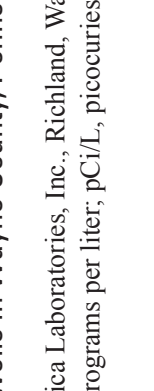 & 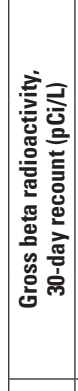 & 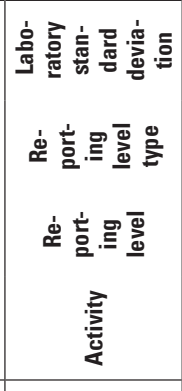 & 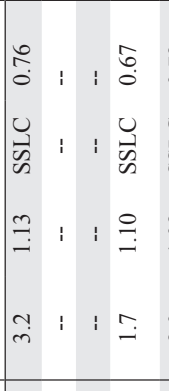 & 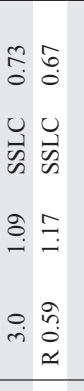 & $\begin{array}{l}\stackrel{ \pm}{=} \\
\stackrel{0}{-} \\
\end{array}$ & 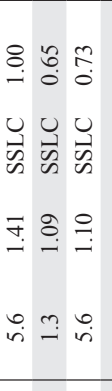 & 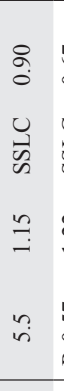 & 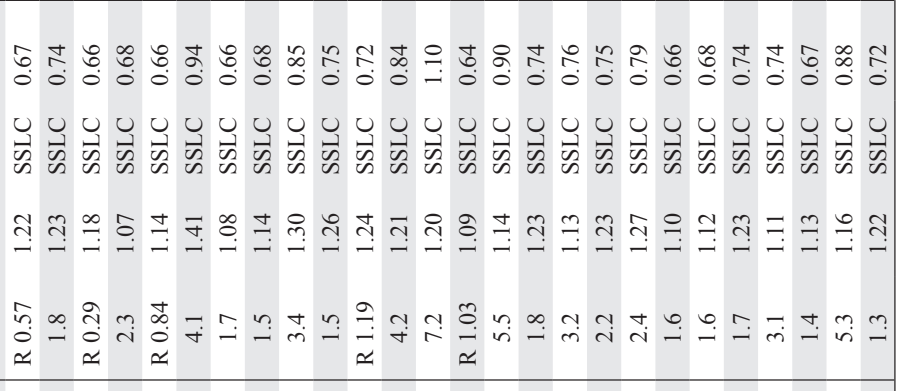 \\
\hline 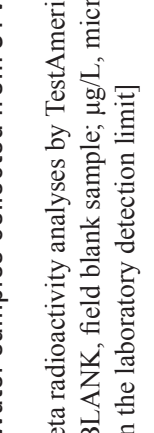 & 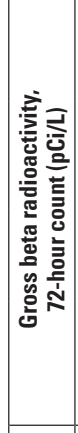 & 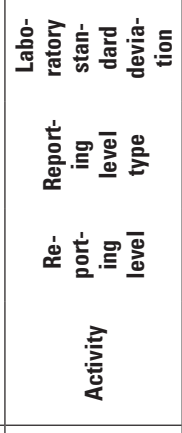 & 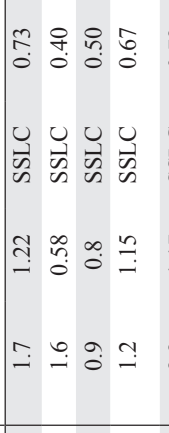 & 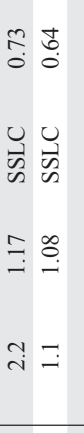 & 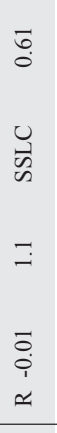 & 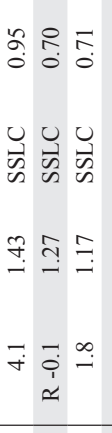 & 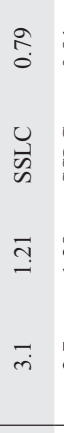 & 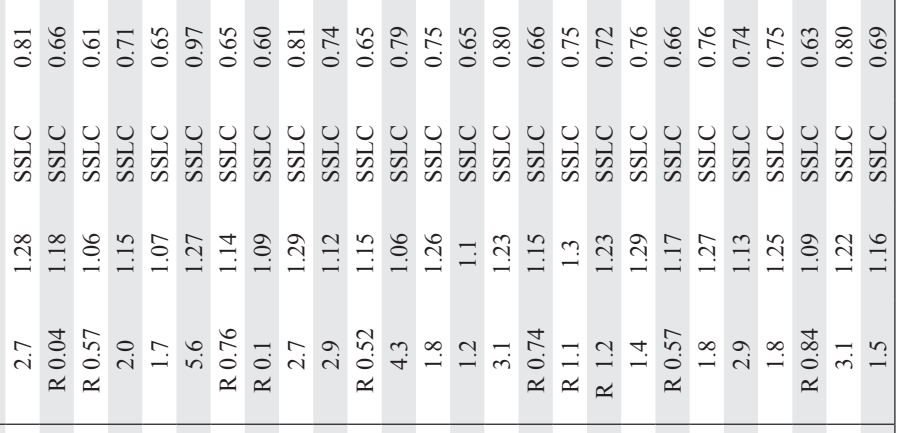 \\
\hline 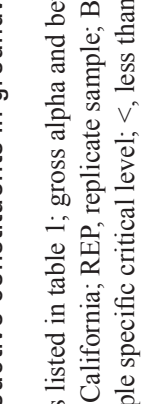 & 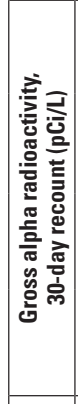 & 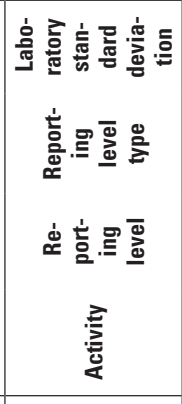 & 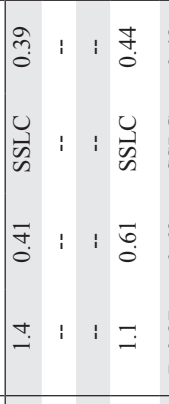 & 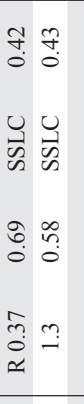 & $\begin{array}{l}\hat{a} \\
0 \\
0 \\
\vec{w} \\
\infty\end{array}$ & 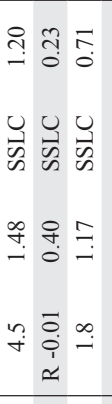 & 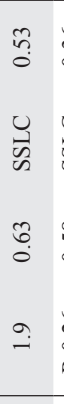 & 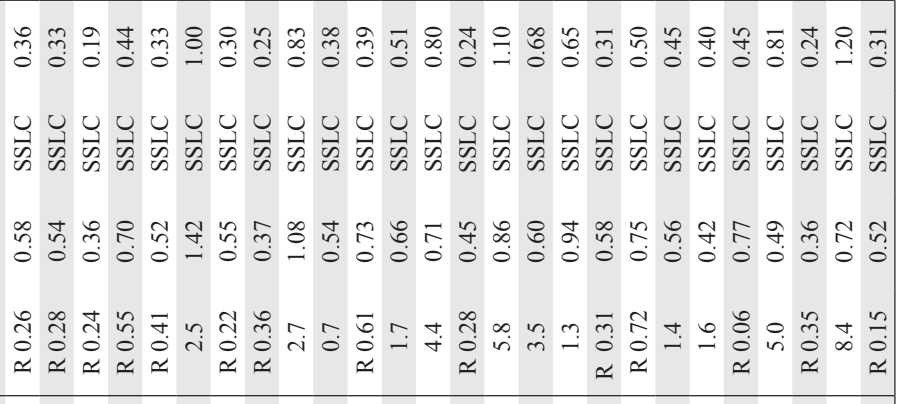 \\
\hline 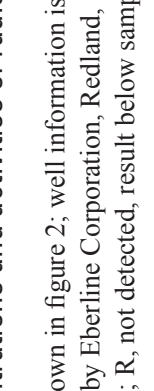 & 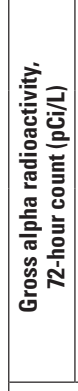 & 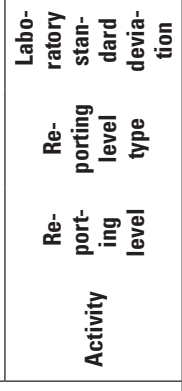 & 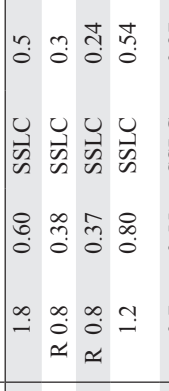 & 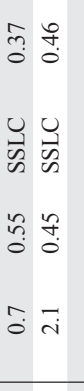 & $\begin{array}{l}\stackrel{+}{m} \\
0 \\
m \\
i\end{array}$ & 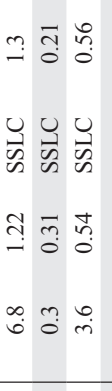 & $\begin{array}{l}\stackrel{5}{0} \\
\stackrel{\circ}{\circ} \\
\stackrel{\dot{m}}{\circ}\end{array}$ & 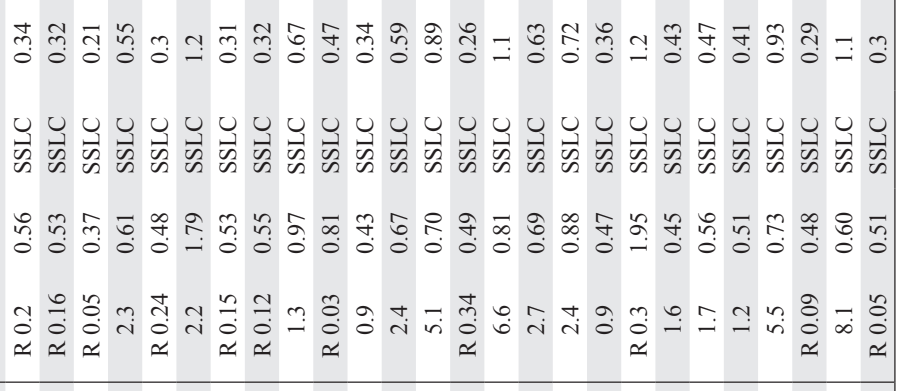 \\
\hline 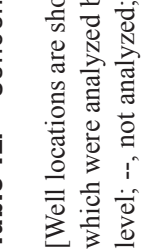 & & 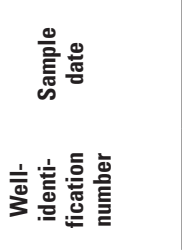 & 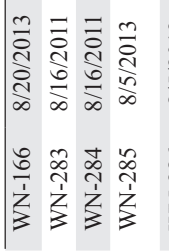 & 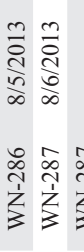 & & 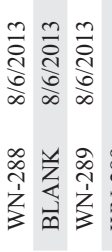 & & $\begin{array}{ll}0 \\
0\end{array}$ \\
\hline
\end{tabular}


Prepared by USGS West Trenton Publishing Service Center. Edited by Ruth M. Larkins.

Layout by Timothy W. Auer.

For additional information, contact:

Director, Pennsylvania Water Science Center

U.S. Geological Survey

215 Limekiln Road

New Cumberland, PA 17070-2424

or visit our Web site at: http://pa.water.usgs.gov 
